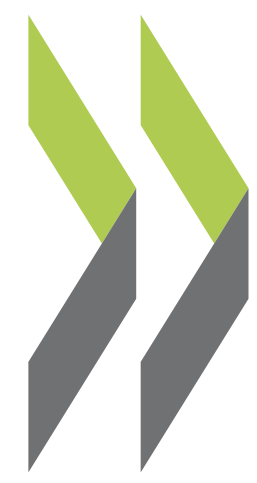

OECD Science, Technology and Industry Working Papers $2004 / 02$

Triadic Patent Families Methodology
Hélène Dernis,

\section{Mosahid Khan}


DIRECTORATE FOR SCIENCE, TECHNOLOGY AND INDUSTRY

\section{TRIADIC PATENT FAMILIES METHODOLOGY}

STI WORKING PAPER 2004/2

Statistical Analysis of Science, Technology and Industry

Hélène Dernis and Mosahid Khan 


\section{STI Working Paper Series}

The Working Paper series of the OECD Directorate for Science, Technology and Industry is designed to make available to a wider readership selected studies prepared by staff in the Directorate or by outside consultants working on OECD projects. The papers included in the series cover a broad range of issues, of both a technical and policy-analytical nature, in the areas of work of the DSTI. The Working Papers are generally available only in their original language - English or French - with a summary in the other.

Comments on the papers are invited, and should be sent to the Directorate for Science, Technology and Industry, OECD, 2 rue André-Pascal, 75775 Paris Cedex 16, France.

The opinions expressed in these papers are the sole responsibility of the author(s) and do not necessarily reflect those of the OECD or of the governments of its member countries.

\section{http://www.oecd.org/sti/working-papers}




\title{
TRIADIC PATENT FAMILIES METHODOLOGY
}

\author{
Hélène Dernis and Mosahid Khan
}

\begin{abstract}
Patent indicators - within the science and technology ( $\mathrm{S} \& \mathrm{~T})$ context - are used to measure inventive performance, diffusion of knowledge and internationalisation of innovative activities - across countries, firms, industries, technology areas, etc. A common approach is to calculate patent indicators based on information (filings, grants, etc.) from a particular patent office. While the richness and strength of those indicators are broadly recognised, they are affected by "home" advantage bias - where proportionate to their inventive activity, domestic applicants tend to file more patents in their home country compared to foreign applicants.
\end{abstract}

Patents taken in various countries to protect inventions can be linked together to build triadic patent families: a set of patents taken at the European Patent Office (EPO), the Japanese Patent Office (JPO), and the US Patent and Trademark Office (USPTO) that share one or more priorities. Patent families are derived from priority application (first filing to a patent office for a patent to protect an invention). A single priority may lead to several patents or a single patent may include several priorities.

This paper illustrates the process of defining patent families and outlines the methodology used to build triadic patent families. In order to develop a definition of patent families, two methodological choices (which have significant impact on the statistics) have to be made. The first methodological choice is to select the optimal geographical filter to determine country coverage (i.e. which and how many patent offices). The second methodological choice is to select the appropriate consolidation filter to relate all patents that refer to the "same invention". In this paper both of those issues are discussed in detail; and alternative definitions are developed and tested against each other to determine the optimal definition of patent families. The selection of one definition over another is determined by the phenomena that are to be measured. The definition presented in this paper is best suited for measuring inventive performance across the OECD countries as it improves the quality (by capturing the more valuable inventions) and international comparability (by eliminating the biases associated with traditional patent indicators) of patent indicators. 


\title{
MÉTHODOLOGIE RELATIVE AUX FAMILLES TRIADIQUES DE BREVETS
}

\author{
Hélène Dernis et Mosahid Khan
}

\begin{abstract}
Resumé
Les indicateurs sur les brevets sont utilisés, dans le cadre de la science et de la technologie (S-T), pour mesurer les performances de l'innovation, la diffusion du savoir et la mondialisation des activités innovantes dans les pays, les entreprises, les industries ou les domaines technologiques. Une technique fréquemment utilisée pour leur comptage consiste à s'appuyer sur les informations (nombres de demandes, de délivrances, etc.) d'un office de brevets spécifique. Si la richesse et l'importance de ces indicateurs sont largement reconnues, leur fiabilité n'en est pas moins soumise à des biais liés à l'avantage national : proportionnellement à leurs activités de découverte, les demandeurs nationaux déposent généralement davantage de brevets dans leur pays d'origine que les demandeurs étrangers.
\end{abstract}

Les brevets déposés dans divers pays pour protéger des inventions peuvent être regroupés en familles triadiques de brevets : un groupe de brevets déposés auprès de l'Office européen des brevets (OEB), du Japanese Patent Office (JPO), et de l'US Patent and Trademark Office (USPTO) qui ont une ou plusieurs priorités en commun. Les familles de brevets sont dérivées d'une demande prioritaire (première demande de brevet effectuée auprès d'un office de brevets afin de protéger une invention). Une seule demande prioritaire peut donner lieu à plusieurs brevets et un seul brevet peut comprendre plusieurs priorités.

Le présent document donne un aperçu du processus de définition des familles de brevets et expose la méthodologie adoptée pour constituer les familles triadiques de brevets. Pour élaborer une définition des familles de brevets, il est nécessaire d'opérer deux choix méthodologiques (qui ont des incidences majeures sur les statistiques). Le premier consiste à déterminer le filtre géographique permettant de sélectionner au mieux les pays concernés (quels offices de brevets nationaux choisir ? À quel nombre se limiter ?). Le second concerne la désignation d'un filtre de regroupement approprié, afin de rassembler tous les brevets portant sur la «même invention». Dans le présent document, ces deux questions sont analysées en détail; l'élaboration et la comparaison de plusieurs définitions permettent d'aboutir à la définition la plus satisfaisante des familles de brevets. Le choix d'une définition particulière dépend des phénomènes à mesurer. La définition proposée dans le présent document est tout particulièrement adaptée à l'évaluation des performances des pays de l'OCDE en termes d'innovation car elle améliore la qualité (en prenant en compte les inventions les plus intéressantes) et la comparabilité internationale (en supprimant les biais liés aux indicateurs classiques sur les brevets) des indicateurs relatifs aux brevets. 


\section{TABLE OF CONTENTS}

\begin{tabular}{|c|}
\hline Introduction.. \\
\hline 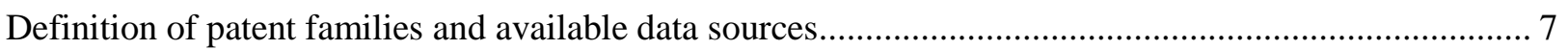 \\
\hline 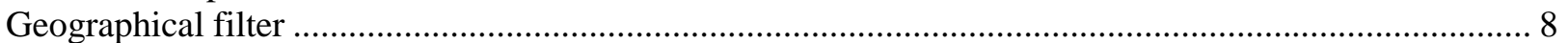 \\
\hline Comparing patent families based on alternative geographical filters \\
\hline Consolidation filter....... \\
\hline 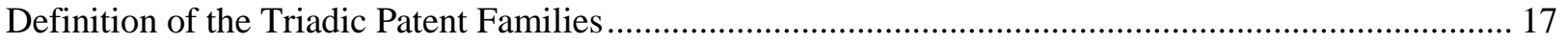 \\
\hline Criteria for counting patent families \\
\hline Measuring inventive performance of the OECD countries using triadic patent families............................ 20 \\
\hline Conclusion \\
\hline
\end{tabular}

ANNEX TABLES 


\section{Introduction}

1. In statistical publications, the common standard is to report patent indicators based on information (filings, grants, etc.) from a particular patent office (henceforth single-office indicators). While the richness and strength of those indicators are broadly recognised, they show specific weaknesses in measuring technological performance. A widely known problem associated with this type of indicator is the "home" advantage bias, where, proportionate to their inventive activity, domestic applicants tend to file for more patents in their home country compared to foreign applicants. This point can be illustrated by a simple comparison of the country share of patent filings to two patent offices, such as the EPO and the USPTO. In 1997, the United States accounted for 53\% of the total USPTO patent grants compared to $16 \%$ for the European Union. The European Union on the other hand accounted for $47 \%$ of total EPO applications, compared to $29 \%$ for the United States (Figure 1). Measuring inventive performance of the European Union and the United States based on patent filings only to the EPO and the USPTO will provide a conflicting message. For a majority of countries, there is a significant difference in the country share of patent filings to the EPO and the USPTO (see Annex table 1).

\section{Figure 1. Country shares of patents applied for at the EPO and patent grants by the USPTO for priority year 1997}

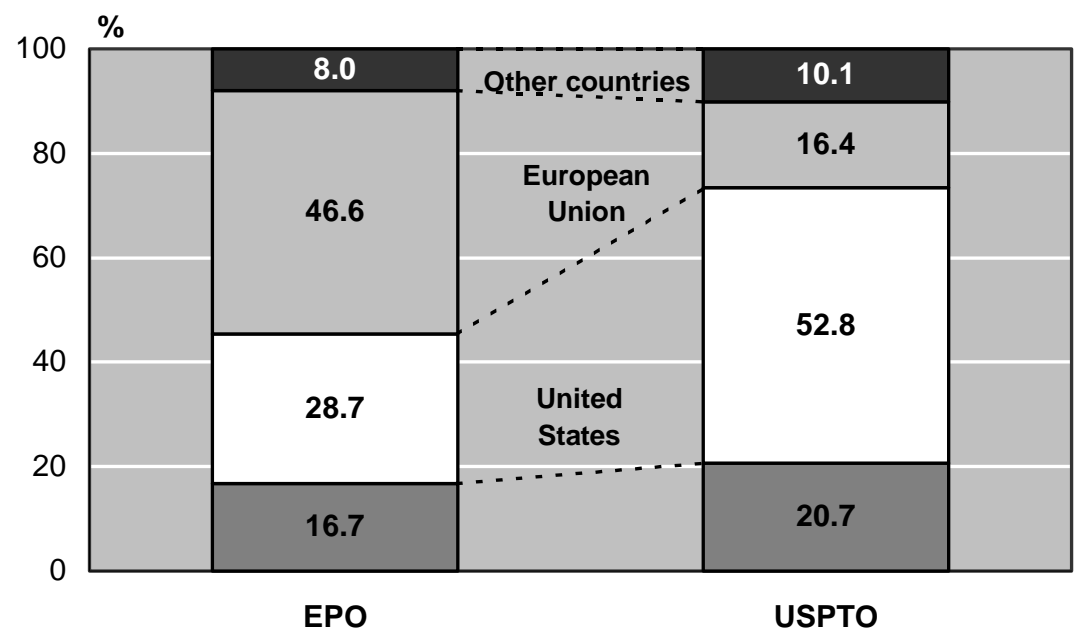

Source: OECD, Patent Database, October 2003.

2. A single patent indicator can be designed by selecting alternative criteria to address different policy issues. Choosing the relevant methodology for counting patents is important as it has substantial impact and implies different interpretations for the derived indicators. The decision to select one criterion over another depends on the phenomena to be analysed (for further details, see OECD, 2003). Patent indicators - within the science and technology (S\&T) context - are used to measure inventive performance, diffusion of knowledge and internationalisation of innovative activities - across countries, firms, industries, technology areas, etc. The requirement here is to develop robust patent indicators (high quality ${ }^{1}$ and comparable across the OECD countries) to address S\&T policy related issues. This point is important, as it will have bearing on the choice of the most relevant criterion. This paper outlines the methodology used to build patent families and provides discussions on various methodological choices involved in designing the optimal patent indicators. It is presented with an eye towards stimulating discussion as well as contributing

1. The value distribution of patents is skewed as many patents have no industrial application (hence, are of no value to society), whereas others are of substantial value. The aim here is to develop patent indicators based on patents that are of similar value. This will improve the quality of patent indicators. 
to the construction of a broader set of methodological papers associated with the development of the OECD's patent database and indicators.

\section{Definition of patent families and available data sources}

3. The concept of patent families is a generic term, which could be refined (using appropriate filters) to design various specific type of indicators to meet various user needs. The principle behind patent families is to trace and match all the subsequent filings originating from the initial patent filing (priority). At the EPO, patent families are defined as: "a group of patent filings that claim the priority of a single filing, including the original priority forming filing itself and any subsequent filings made throughout the world" (Hingley and Park, 2003). Derwent Information Ltd. defines patent families as follows: “... if protection is sought in more than one country, or through more than one patenting authority, this will result in what is known as a family of patents".

4. During the last decades, several databases have been designed to enabling international comparisons of patents, of which the World Patent Index (WPI) developed by Derwent; DOCDB and INPADOC databases set up by the EPO. The WPI supplies value-added patent documents published in the world: each patent document is assessed, classified and indexed at the priority level by a group of experts, in order to facilitate specific technological searches and invention comparisons. It enables companies to view the state of art in innovative domains. The EPO maintains a comprehensive data file of patent families (PRI), which is based on the publication database (DocDB). The PRI data file includes, for each invention, the priority number of the first filing plus a description of the subsequent patenting activities for that invention in four major economic blocs - EPO and EPC contracting states, Japan, USA and other countries (Hingley and Park, 2003).

5. According to the EPO definition, a patent family could consist of a set of patents within a single patent office, i.e. domestic patent applications in one country with no foreign equivalent. Under specific circumstances, it may be desirable to include such families: for example, if the objective is to measure only the level of domestic innovative activity, then patent families based on single-office may be sufficient enough. However, the purpose here is to develop statistics that would improve the quality and international comparability of the technology output indicator: the scope of patent families should be extended to other offices for reducing the home advantage bias.

6. As a starting point, a patent family is defined as: a set of patents (originating from the priority filing) taken in various countries (i.e. patent offices) to protect the same invention. By applying the appropriate filter to the general definition, patent families indicators can be designed to meet specific user needs, determined by the phenomena to be measured. The general definition adopted here already includes a filter to rule out families based on a single office: patent has to be taken in various offices, i.e. at least two patent offices.

7. The quality and international comparability of indicators based on patent families is improved by reducing (in some cases eliminating) the weaknesses associated with traditional patent indicators (indicators derived from a single patent office). A domestic plus a foreign filing is a necessary condition for being a member of patent families: the home advantage bias being reduced or eliminated. Counting patent families also avoids double counts of a specific invention in a world-wide scale ${ }^{2}$, and diminishes

2. Double counting occurs when a domestic application is followed by a foreign application (usually within 12 months). For example, an application is filed with the USPTO, which is also filed to the EPO. Counting patent based on filings to the USPTO and the EPO will count the same invention twice. 


\section{DSTI/DOC(2004)2}

biases resulting from special bilateral relationships ${ }^{3}$. When patent counts are based on single office, many patents with little or no value are included while few are extremely valuable (skewed distribution of patents' value). Furthermore, it is difficult to compare domestic filings with foreign patent applications since the average value of foreign patents might be higher than that of the domestic ones, due to the self selection process ${ }^{4}$. The self selection process occurs when the inventor (applicant) - usually filing for protection at the domestic patent office - extends the protection to foreign countries. Only a proportion of the total domestic patents are subsequently filed abroad: extending protection to foreign countries increases the costs of patenting for the inventor (additional patent office fees, translation costs, attorney fees, etc.). The inventor (applicant) will only accept these additional costs on the condition that expected revenues outweigh patenting costs. As a consequence, patent families tend to capture the most economically important inventions and - to certain extent - the inventions included in the data set are comparable to each other. Furthermore, due to the rules and regulations within patent offices, comparing patent counts based on different patent offices (e.g. USPTO vs EPO) is limited: differences in processing and publishing patent filings, scope of patent protection, etc. Thus, identifying patent families might improve the comparability of indicators by eliminating the impact of country's specific rules and regulations.

8. For the purpose of measuring inventive performance, two filters have to be introduced to the general definition of patent families: a) a geographical filter to determine the coverage of the term "various countries", and b) a consolidation filter to cover all patent data that refer to a "same invention".

9. Results and robustness test of indicators based on several definitions of families are discussed in the next section. Patent families are derived from the following raw data: DocDB database (administered by the EPO) is the main data source covering world-wide patent applications, complemented with EUREG database (administered by EPO), and patent data from the USPTO (Internet site). All data refer to patent applications, except for the USPTO data which are based on patent grants. Until recently (beginning 2001), the only historical record of a patent published by the USPTO consisted in patent grant documents.

\section{Geographical filter}

10. Understanding the patenting process is important for selecting the optimal geographical filter (i.e. which and how many patent offices). The most widely used method for protecting an invention involves filing a patent application to a national patent office, which establishes a priority right ${ }^{5}$ (Paris Convention, 1883). The first application date is commonly referred to as priority date. Afterwards, if the inventor (or applicant) wishes to protect his/her invention in countries apart from the domestic market, he/she can file for a patent either in each country in which protection is desired, or to a regional office such as the EPO, or he/she can file an international application using the PCT procedure ${ }^{6}$ (for further details see,

3. For example, Japan has a high level of patent activity at the national patent office of Germany (DPMA). Similarly, Canada has a high level of patenting activity at the USPTO.

4. Attributing monetary value to individual patent is extremely difficult. Here, the term value of patent is used in the sense that the inventor is willing to accept additional cost of patenting abroad, because he finds it to be valuable (expectation is that the revenue will outweigh the additional costs).

5. The Paris Convention established the equal rights for the nationals of each member state, and established the system of priority rights. See Article 4 of the Paris Convention (www.wipo.org/treaties/ip/paris/index.html). Under the priority rights, applicants have up to 12 months of grace period to extend the initial patent application to other member countries and claim the earliest priority date. Priority date is important in patent filing process as it is used to determine the novelty of inventions.

6. Filing a patent application does not lead to automatic protection of the invention. The invention is protected by patent rights if the application is successful. 
OECD, 2003). Rights are attributed to the applicant from to the priority date if the external application(s) is filed within 12 months after the first filing. Patenting procedures are institutionally different in Europe, Japan and the United States. For protecting inventions in Japan or in the United States, applications are directly filed at the JPO or the USPTO, respectively. However, for protecting inventions in Europe ${ }^{7}$, applicants have the choice of filing for applications to the national patent offices or directly to the EPO. Successful filings to the EPO (i.e. patents granted) are transferred to the national patent offices that were designated in the application without any further examination by national patent offices ${ }^{8}$.

11. The threshold for the geographical filter is determined by the phenomena to be measured. A stringent ${ }^{9}$ filter (e.g. more than 2 patent offices) will make it difficult for a patent to be a member of the families, as additional countries covered by the filter will increase the total cost of patenting. The general definition of patent families outlined above implies that the most lenient geographic filter will consists of a two-office filter; i.e. patent applications within at least two patent offices being a necessary condition for being a member of the patent families. In a majority of cases, a domestic patent application will be followed by a subsequent foreign application ${ }^{10}$. Therefore, indicators based on a two-office filter will improve the quality and international comparability of traditional patent counts, but they will still be affected by trade flows and market size biases. Furthermore, under specific circumstances, the indicators will also be affected by the home advantage bias. The commercial strategy is a key factor in patenting: if one wants to sell a new product on a given market, then patent protection is important to safeguard potential revenue. Consequently, patent filings are influenced by trade flows. If strong bilateral trade relationships exist between two countries, then patenting activity between those countries will be higher than for remote countries without any trade links. Similarly, indicators are affected by market size bias. Consider the case of Canada with respect to patent applications to the United States. The incentive for the Canadian inventors to protect their inventions in the US market is much higher than for the incentive for the US inventors for protecting their inventions in the Canadian market. This is reflected in the patenting statistics as shown by Figure 2, which shows the number of patent granted by the USPTO to Canadian inventors. Canadian inventors prefer to file for application with the USPTO in the first instance, and a subsequent application to the Canadian patent office. In the 1980s, approximately $75 \%$ of the Canadian patents in the USPTO had a US priority with no equivalent Canadian priority and this ratio increased to around $85 \%$ during the 1990 s.

7. In the context of patenting procedure, Europe refers to the 27 member countries (as on June 2003) of the European Patent Convention, rather than the European Union which has 15 member states (as of June 2003).

8. Grant of a patent application by the EPO did not confer a patent in all the EPC member states: patent is conferred only for the designated states.

9. Stringent in the sense that patent families based on three-office filter will be more stringent than patent families based on two-office filter.

10. It is possible to have a patent document with two foreign applications with no domestic equivalent, but such cases will be very rare. 
Figure 2. Number of USPTO patents invented by Canadian resident, simple counts, by priority year

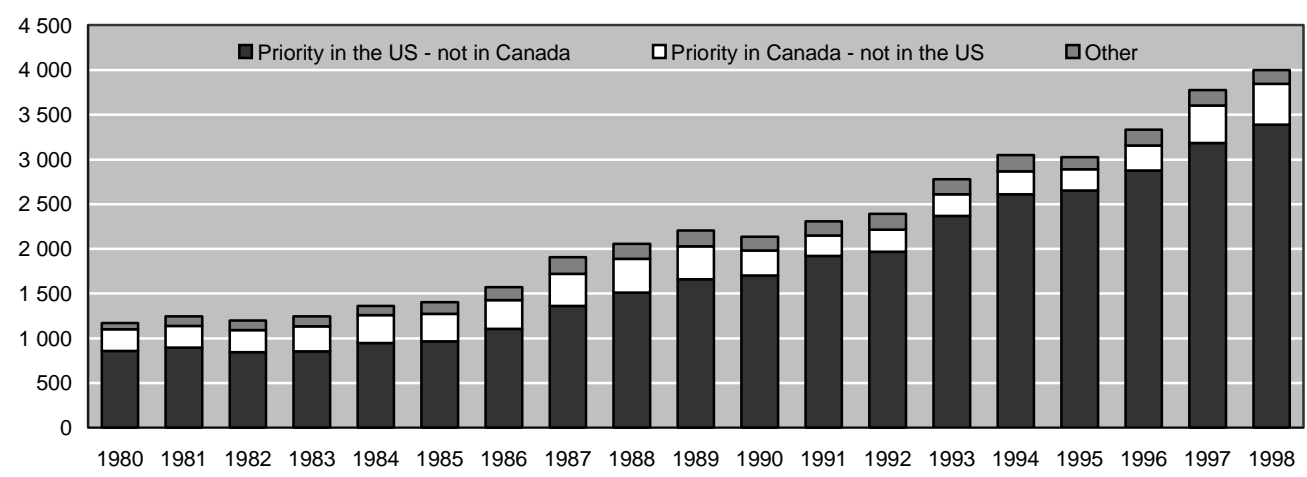

Source: OECD, Patent Database, October 2003.

12. EPO patents could also be considered as patent families, if the definition is based on a two-office filter. In most cases, the EPO filing procedure consists of the following steps: an initial application is filed at the national patent office, and, within one year, a subsequent patent is applied for at the EPO to protect the invention in the designated EPC member countries. Such protection route fulfils the condition of the geographical filter previously stated: including filings to at least two patent offices. Around $7.5 \%$ of the EPO patent applications bypassed the national filing in the first instance (EPO priority) over the period 1990-1999. Furthermore, any successful EPO priority applications are transferred to the national patent offices ${ }^{11}$ in a latter date, and as a consequence, successful EPO priority filings will fulfil the condition of the two-office filter. However, indicators based on the EPO filings still suffer from the home advantage bias, at least for European countries (see Figure 1).

13. The above discussion has illustrated that patent families indicators based on a two-office filter are subject to various biases (home advantage, trade flows, market size, etc.). To cope with these weaknesses, the threshold of geographical filter should be strengthened to include information from at least three patent offices. The relevant patent offices should cover the major economic zones that a) account for a significant proportion of the world-wide patent filings; b) are advanced in technological areas and c) account for the majority of the world-wide R\&D efforts. Patent offices in Europe, Japan and the United States fulfil these conditions, hence those offices are selected for the geographical filter. Protecting invention in the United States (or in Japan) consists of filing an application to the USPTO (or to the JPO), whereas for Europe the scenario is slightly different. There are two options for filing in Europe: filing an application either to the national offices or to the EPO. Either approach could be taken into account. To determine whether national patent filings of the EPC countries (European Patent Convention) should be included in addition to EPO filings and their impact on the derived indicators, patent families have been calculated and compared according to three different definitions.

14. The geographical filter for the first definition of patent families refers to patent filings to the EPO, the JPO and the USPTO (definition A). The second definition is based on patent filings to the JPO, the USPTO and to either the EPO, or jointly to the French and the German and the United Kingdom Patent offices (definition B). The third definition (definition C) covers patent filings to the JPO, the USPTO and either to the EPO or to the national patent office of France (INPI), or Germany (DPMA), or United Kingdom (UKPO). The strength of the filters differs across these three definitions - definition A has a

11. Patents that have been granted by the EPO will be transferred to designated countries. The number of designated countries will exceed one, because of the high fees associated with EPO application. EPO filing is cost effective if the inventor wants to protect the invention in 4 or more countries (Grupp and Schmoch, 1999). 
stronger filter than that of definition B, which in turn is stronger than that of definition $\mathrm{C}$. The main reasons for focusing on the patent offices of France, Germany and the United Kingdom are that they represent the three largest patent offices (volume of patent applications) within the EPC countries, and inventors from those three countries account for a significant proportion of the EPO and USPTO patents. Additional tests were conducted on the inclusion of filings from the national patent offices of Italy, the Netherlands and Sweden. However, analysis of the results showed that once the three large European patent offices are covered in the definition, extending the filter to other patent offices does not significantly alter the structure of patent families. In this paper, only the results for patent families counted according to definition A, B and $\mathrm{C}$ are reported.

Definition A: filings to the JPO and the USPTO and the EPO

Definition B: filings to the JPO and the USPTO and [filings to the EPO or filings to (INPI and DPMA and UKPO)]

Definition C: filings to the JPO and the USPTO and [filings to the EPO or filings to INPI or filings to DPMA or filings to UKPO]

\section{Comparing patent families based on alternative geographical filters}

15. Definition A has a stronger geographical filter than that of definition B and C. Hence a prior expectation is that patent families calculated using definition $\mathrm{A}$ will be less subject to biases (home advantage, bilateral trade flows, etc.) in comparison to patent families based on definition B and C. Furthermore, the volume of patent families counted with a strong geographical filter will be lower than the volume of patent families calculated using a weak geographical filter, i.e. $\mathrm{TPF}_{\mathrm{A}}<\mathrm{TPF}_{\mathrm{B}}<\mathrm{TPF}_{\mathrm{C}}(\mathrm{TPF}$ : triadic patent families). Here, patent families according to definition A will act as the benchmark to which other definitions will be compared to. Therefore, the tests will focus on whether introducing a weaker geographical filter (i.e. expanding the patent office coverage) introduces biases and national specificities in patent families indicators ${ }^{12}$. The EPO was set up in 1978: during the transition period, the number of filings was relatively small, increased at a rapid pace and the propensity of EPO filings varied across countries. Therefore pre-1985 data have been excluded from the calculation of patent families.

\section{Definition A versus definition B:}

16. As expected, with the inclusion of patents filed with the national patent office of Germany, France and the United Kingdom, along with the EPO, JPO and USPTO, total patent families count is increased by $3.2 \%$ on average for the $1985-97$ period (see Annex table 2). The increase in the number of patent families is of the same magnitude (around 3\%) for the European Union, Japan and the United States. Definition B adds 3.8\% more families for Germany, 2.0\% for France, 2.1\% for the United Kingdom and less than $1 \%$ for the Netherlands. An exception to these difference levels being Korea, where the number of patent families is significantly higher with the geographical filter of definition B (53\% additional patent families on average over the same time period). It reflects a specific patenting strategy of Korean inventors for protecting their inventions in the European market: 1/5 of Korean patents in the families were filed respectively to the JPO, USPTO, INPI, DPMA and UKPO and not to the EPO in the later years.

12. Rather than selecting definition $\mathrm{A}$ as the benchmark definition, definition $\mathrm{C}$ could have been selected as the benchmark definition, which has a weaker filter (compare to definition A). In that case, the focus of comparing patent families data would have been to test whether introduction of stronger filter (definition A) reduces bias and national specificities. 


\section{DSTI/DOC(2004)2}

17. The proportion of patent families that circumvent the EPO is decreasing over time. In 1997, less than $1.1 \%$ of total patent families went through the INPI-DPMA-UKPO filter, compared to $2.7 \%$ in 1990 (see Figure 3 below). The convergence of the two methods over time reflects the institutional progress of the EPO. For most major European countries, there was a slow transition of the proportion of filings following the EPO procedure. The transition took place through the 1980's and did not stabilise until the 1990's. Since then, the usage of the EPO has become more frequent, as it facilitates the protection of inventions across the EPC states. However, among countries with more than 100 patent families in 1997, only 3 OECD countries have more than $1 \%$ of data added by the filter from definition B. This percentage reaches $21 \%$ for Korea (579 patent families under definition B against 700 with definition B), and stands around $2.7 \%$ for Austria and $1.5 \%$ for Germany. The persistent differences for Austria and Germany result from the home advantage bias: to protect an invention in Europe, the inventor/applicant will file a priority application in DPMA, and after one year time extend the protection to France and the United Kingdom.

Figure 3. Percentage differences between definitions A and B, by priority date and country of invention

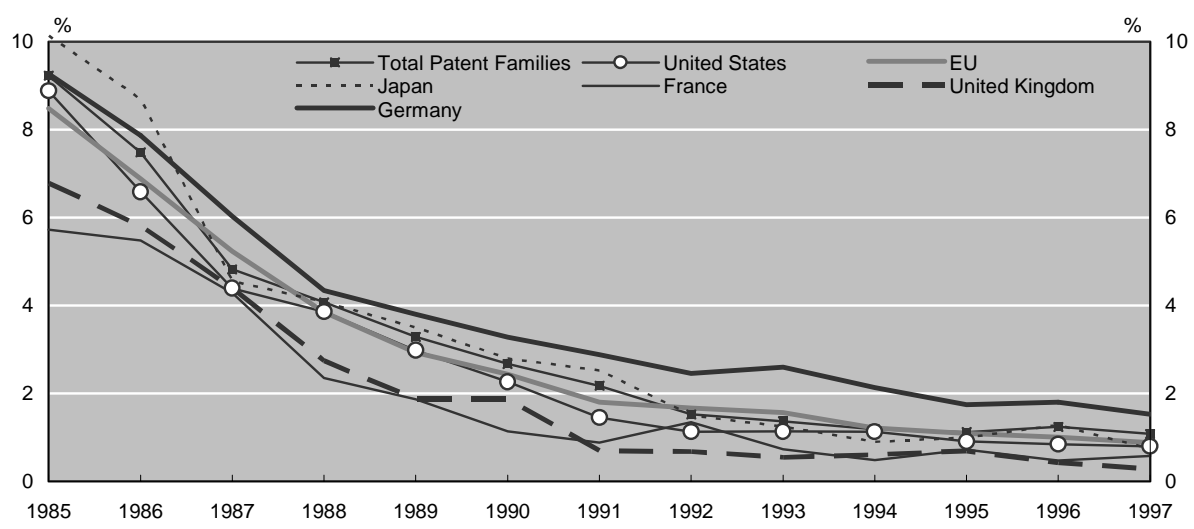

Source: OECD, Patent Database, October 2003.

18. Even though the use of filter B results in additional patent families (especially in Korea), it does not affect the countries' breakdown (see Annex tables 4 and 5). Country shares are slightly altered for Germany, Japan, the United States and Korea, with an absolute difference of less than 0.2 percentage points in 1997. The ranking of countries according to their respective shares is not modified by the filter of definition B for major patenting countries. Korea is the most noticeable exception, as it gains 2 positions compared to definition A. Country shares are highly correlated over time for countries with a large patenting activity: the correlation coefficient exceeds 0.98 for most of these countries on the period 1985-97. Shares tend to be more volatile for smaller countries such as Czech Republic and Luxembourg, where the number of patent families is rather small.

19. The following test was performed in order to assess whether country shares over total patent families are not significantly altered by the use of a weaker filter. The null hypothesis assumes that the average country shares with both definition $\mathrm{A}$ and $\mathrm{B}$ to be equal; the alternative hypothesis being that the shares are significantly distinct:

$$
\begin{aligned}
& H_{0}: \mu_{B}=\mu_{A} \\
& H_{1}: \mu_{B} \neq \mu_{A}
\end{aligned}
$$

where $\mu_{A}$ and $\mu_{B}$ represent the mean of the country shares under definition A and B. The test statistics is calculated as follows:

(1) $t=\left(\frac{\tilde{\mathrm{Y}}_{\mathrm{A}}-\tilde{\mathrm{Y}}_{\mathrm{B}}}{\sigma}\right) \sqrt{\frac{n_{A} n_{B}}{\left(n_{A}+n_{B}\right)}}$ 


$$
\text { (2) } \sigma=\sqrt{\frac{n_{A} s_{A}{ }^{2}+n_{B} s_{B}{ }^{2}}{\left(n_{A}+n_{B}-2\right)}}
$$

where $n_{\mathrm{A}}$ and $n_{\mathrm{B}}$ are the number of observations, $\mathrm{s}_{\mathrm{A}}$ and $\mathrm{s}_{\mathrm{B}}$ the respective standard deviations, and $\sigma$ the common standard error. The test statistic is t-distributed with $\left(n_{\mathrm{A}}+n_{\mathrm{B}}-2\right)$ degrees of freedom. A significant large value (positive or negative) of the empirical t-ratio would reject the null hypothesis in favour of the alternative, implying that the country shares are significantly different. The t-ratios calculated on the period 1985-97 are below the critical values derived from a t-distribution at 28 degrees of freedom for all countries. This result confirms the acceptation of the null hypothesis for all OECD countries (see Annex Table 4): the use of the geographical filter B does not alter the average shares of countries in patent families.

20. As a conclusion, the use of a geographical filter enlarged to filings at the INPI, DPMA and UKPO does not add a significant amount of information in total patent families for the later years (only 614 additional patent families in 1997 over 57 700). The numbers of additional patent families have persistently decreased over time, reaching a negligible proportion of families for nearly all OECD countries (less than $1 \%$ in the later years). However, there is a remaining home advantage bias in families calculated under definition B: Austria, Germany and Korea show a minor but persistent behaviour of regularly circumventing the EPO by filing for applications altogether to INPI, DPMA and UKPO.

\section{Definition A versus definition C:}

21. The filter used under definition $\mathrm{C}$ is less selective than that of definition $\mathrm{B}$ : to be a member of a patent family, a patent has to be filed for at the JPO, the USPTO, and either to the EPO or to INPI, DPAM or UKPO. This condition is weaker in the sense that protection requested only in France will be considered as a patent application in Europe, even if the protection does not cover any other European countries. Therefore, a patent with a French priority that was subsequently applied for at the JPO and at the USPTO will be considered as a patent family.

22. Differences in the number of patent families are a lot larger than those observed when comparing patent families under definitions A and B. Between 1985 and 1997, an average of 19\% patents were added to total patent families by the filter represented by definition $\mathrm{C}$ (see annex table 3 ). The difference varies across countries: $33.6 \%$ more patent families for Japan, 9.7\% for the European Union and $8.7 \%$ for the United States. Even though the differences are decreasing over time, levels remain high in the later years: 3 to $4 \%$ in France, between 9 and 13\% in Germany, between 4 to $6 \%$ in the United Kingdom and more than doubling of the total number of patent families for Korea, from 579 patent families under definition A to 1243 with definition C in 1997.

23. The inclusion of the German patent office (DPMA) to the filter contributes to most of the additional families (DPMA contributes to $9 \%$ of the 12.7\% additional families in 1997). Inventors or applicants from countries such as Japan or Korea willing to protect their invention in Europe tend to focus on direct applications to the DPMA (bypassing the EPO). Therefore, the filter under definition $\mathrm{C}$ tends to introduce bias by integrating patenting strategies of applicants. Country shares are widely affected by the number of patents filed at USPTO, JPO and any one patent office of Europe (see Annex tables 4 and 5). Country shares across definitions are less correlated over time, especially for Japan where differences are more noticeable. The empirical t-statistics reject the null hypothesis of equality of the average shares in the whole period 1985-97, for the bigger patenting countries, such as the France, Japan, Switzerland, the United Kingdom and the United States. The relative order of countries is altered: relative positions of Japan and the United States in 1997 are swapped (Japan represents 28\% of patent families with definition A and more than $31 \%$ under definition C). Japan becomes the major patenting country; and 
Korea increases by 5 positions. This result is inconsistent with other S\&T indicators (R\&D expenditures, scientific publications, etc.).

Figure 4. Shares of selected countries in total patent families comparisons between definition A and C, for priority year 1997
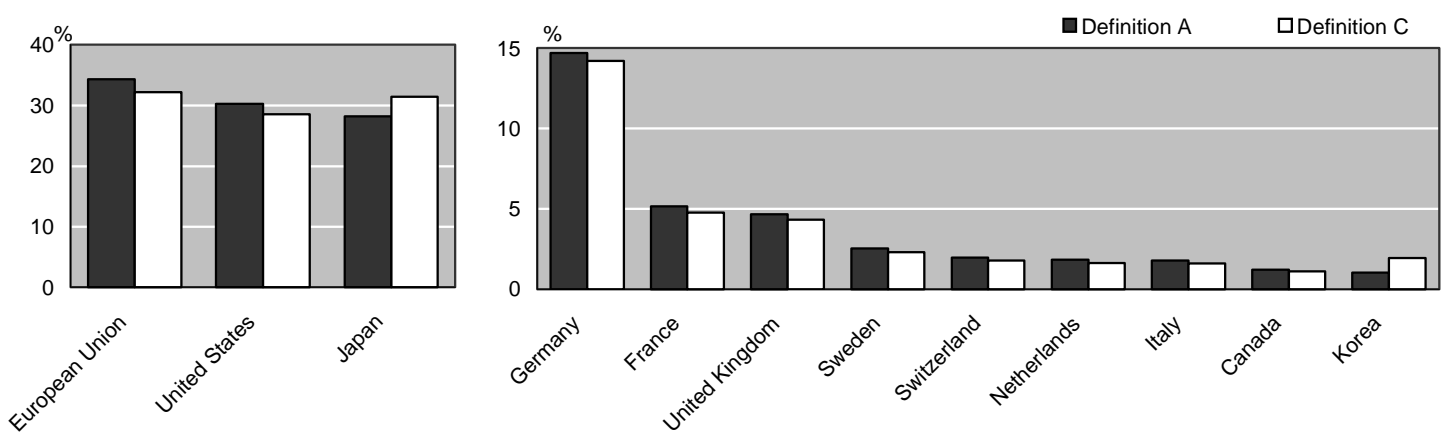

Source: OECD, Patent Database, October 2003.

24. As a consequence, the extension of the geographical filter to European national patent offices reinstates country biases, reflecting patenting strategies of some individual countries into patent families' indicators. For instance, more weight is given to patent applications to DPAM with definition C, and - to a certain extent - to German inventions. For such patents, the "internationalisation" of the protection is restricted to US and Japanese markets.

25. As a conclusion, the numbers of patent families and the country shares are not substantially modified by altering the geographical filter to include patent filings to three mutually exclusive national patent offices from the list of EPC countries, in addition to the EPO filings (definition B). The geographical filter for definition $\mathrm{C}$ allows a single national office to characterize a request for protection in Europe. Thus, a broader geographical coverage does not improve patent based indicators, with respect to cross-country comparisons. Filtering patent families to the patent offices in the triad USPTO, JPO and EPO captures almost all the patent families. Furthermore, "triadic" patent families improve the quality of patent indicators aiming to provide a good measure of technology performance across the OECD countries.

\section{Consolidation filter}

26. In this paper, patent families are defined as a set of patents taken in various countries to protect a same invention. Patent families are derived from the priority application, as it has the closest link to the original invention. To be a member of the patent family, the priority application must have at least one equivalent patent at the EPO, at the USPTO and at the JPO. However, as it was stressed earlier, the rules and regulations of a given patent office, as well as specific patentee's strategies, have an significant influence on the number of applications filed at this office.

27. Therefore, depending on the office, on the patenting strategy and on the level of technology a patent may be designed to protect a unique invention - derived from an unique priority application; it may protect a set of inventions connected by the same or a complementary technology; or several patents may refer to the same invention (patent family based on a single office). As an illustration, JPO patents were restricted to only one claim per application before 1988. It is thus difficult to draw the boundaries of an invention. Consider that 2 patent applications to the JPO may correspond to a unique filing to the EPO or the USPTO: should there be 2 patent families - based on each JPO applications - or 1 patent family based on the EPO or USPTO application? This phenomenon is interpreted as overlaps of priorities within patent offices: a single priority may lead to several patents or a single patent may include several priorities. 
Figure 5. Priorities overlap within patent offices of the triad EPO, JPO, USPTO, for priority date 1997

Number of patents subsequent to a same priority

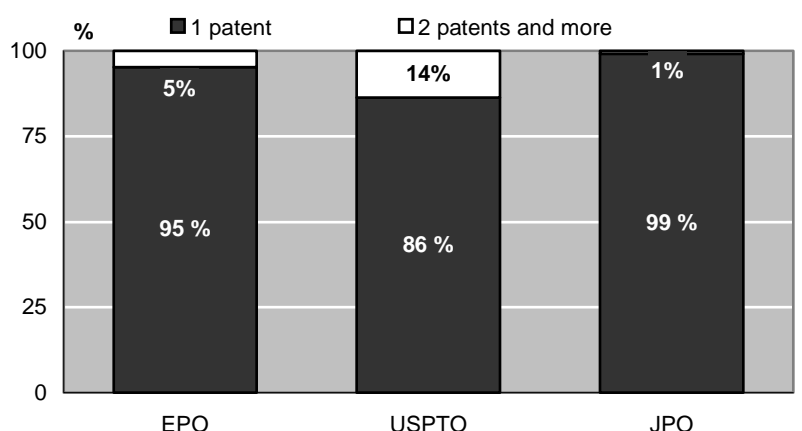

Number of priority applications in a patent document

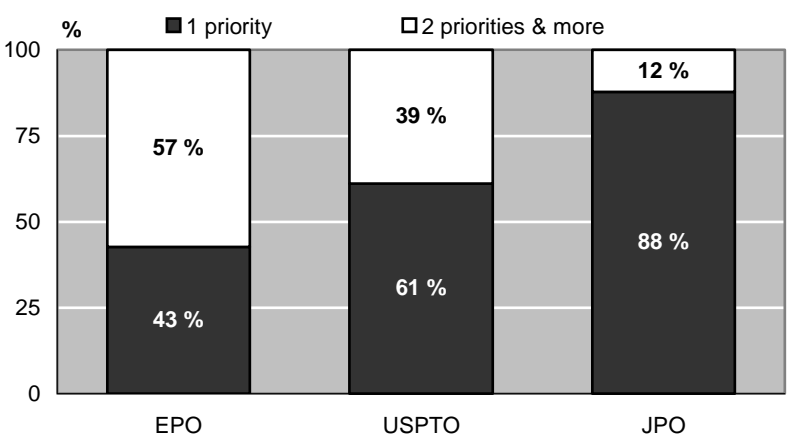

Source: OECD, Patent Database, October 2003.

28. According to Figure 5, 5\% of priorities in 1997 lead to at least 2 distinct EPO filings, this share accounts to $14 \%$ of USPTO patents, and to $1 \%$ of JPO filings. Most priorities are extended to a unique filing to the offices of the triad. Thus, priority overlaps mainly derive from the structure of patent filings themselves. More than $1 / 2$ of patent applications to the EPO refer to a minimum of 2 different priorities, against $1 / 3$ of USPTO patents. The structure of patent documents is sensitive to the patent office where it has been filed, and will affect the final count of patent families.

29. Therefore, an important issue to discuss here is connected with the integration of patents' overlaps in the definition of families. A schematic illustration of patent overlaps is given by the example below, with 8 patent documents taken at the 3 patent offices:

\begin{tabular}{c|c|c}
\hline Patent documents at USPTO & Patent documents at JPO & Patent documents at EPO \\
\hline $\mathbf{U}_{1}:\left\{\right.$ Priority $\mathrm{P}_{1}$, Priority $\left.\mathrm{P}_{2}\right\}$ & $\mathbf{J}_{1}:\left\{\right.$ Priority $\left.\mathrm{P}_{1}\right\}$ & $\mathbf{E}_{1}:\left\{\right.$ Priority $\mathrm{P}_{1}$, Priority $\left._{2}\right\}$ \\
$\mathbf{U}_{2}:\left\{\right.$ Priority $\mathrm{P}_{2}$, Priority $\left.\mathrm{P}_{3}\right\}$ & $\mathbf{J}_{2}:\left\{\right.$ Priority $\left.\mathrm{P}_{2}\right\}$ & $\mathbf{E}_{2}:\left\{\right.$ Priority $\left.\mathrm{P}_{2}\right\}$ \\
& $\mathbf{J}_{3}:\left\{\right.$ Priority $\left.\mathrm{P}_{3}\right\}$ & $\mathbf{E}_{2}:\left\{\right.$ Priority $\left.\mathrm{P}_{3}\right\}$ \\
\hline
\end{tabular}

30. From this sample, one can derive two alternative sets of patent families:

(1) Basic patent families A

$$
\begin{aligned}
& \mathbf{P}_{\mathbf{1}} \subset\left\{\mathrm{U}_{1} ; \mathrm{J}_{1} ; \mathrm{E}_{1}\right\} \\
& \mathbf{P}_{\mathbf{2}} \subset\left\{\mathrm{U}_{1} ; \mathrm{U}_{2} ; \mathrm{J}_{2} ; \mathrm{E}_{1} ; \mathrm{E}_{2}\right\} \\
& \mathbf{P}_{\mathbf{3}} \subset\left\{\mathrm{U}_{2} ; \mathrm{J}_{3} ; \mathrm{E}_{3}\right\}
\end{aligned}
$$

(2) Consolidated patent families $A^{*}$ $\left[\mathbf{P}_{1} ; \mathbf{P}_{2} ; \mathbf{P}_{3}\right]$ : $\subset\left\{\mathrm{U}_{1} ; \mathrm{U}_{2} ; \mathrm{J}_{1} ; \mathrm{J}_{2} ; \mathrm{J}_{3} ; \mathrm{E}_{1} ; \mathrm{E}_{2} ; \mathrm{E}_{3}\right\}$
3 distinct patent families are formed with patents sharing at least one common priority: $\mathrm{P}_{1}$ is included in documents $\mathrm{U}_{1}, \mathrm{~J}_{1}$ and $\mathrm{E}_{1} \ldots$

1 patent family is counted: patents are either directly or indirectly linked to the others: priorities $\mathrm{P}_{1}$ and $\mathrm{P}_{2}$ are both included in documents $\mathrm{U}_{1}$ and $\mathrm{E}_{1} ; \mathrm{P}_{3}$ is directly linked to $\mathrm{P}_{2}$ - via document $\mathrm{U}_{2^{-}}$and thus to $\mathrm{P}_{1}$ indirectly.

31. Triadic patent families counted under the first option are equivalent to patent families designed at the EPO "for describing the flows of demand for patent rights within and between the most economically active geographical blocs" (Hingley and Park, 2003). Option (1) gives a measure of the volume of priorities that were extended to an international level of protection. The major differences between (1) and (2) results from the integration of indirect links between priority filings, even though the weights of each 


\section{DSTI/DOC(2004)2}

linkage between priorities may vary with the nature of the invention and technological linkage it refers to. An invention (priority) may complement, replace or follow a previous invention (priority) to a certain extent that can not be precisely measured at a raw level. However, the consolidation of families tends to lower the impact of patent offices specificities and to neutralise any patenting behaviour by removing most overlaps of priorities.

32. The basic patent families A are counted by identifying the priorities that led to patent filings at the EPO, USPTO and JPO. The consolidation filter is then applied by regrouping the priorities that are inter-related in a EPO, USPTO or JPO patent document. It is expected that the number of patent families will be reduced by this filter. The impact of the consolidation on patent families based indicators will be measured hereafter, using patent families under definition A.

\section{Basic patent families versus consolidated patent families}

33. The rational for consolidation is to reduce the country bias resulting from differing breadths of patents. The consolidation filter lowers the volume of patent families (see Figure 6 and Annex Table 6). A $27 \%$ difference exists between definition A and A* (consolidated) for 1985-97, and is increasing over time. A wider reduction occurs for Japan, where there is an average of $39 \%$ fewer families after the consolidation filter has been applied. Differences of $20 \%$ and $17 \%$ exist respectively for the European Union and the United States. The levels of reduction are consistent with the levels of priorities' overlaps in patent offices: there was little overlap in JPO filings, which lead to a higher number of inventions from Japan and therefore to a higher propensity of overlapping when protection of Japanese inventions are extended to the EPO or the USPTO. Over the 1985-97 period, the volume of patent families (based on definition A) was consolidated respectively by an average of $15 \%$ to $30 \%$ for most European countries as well as Korea and Switzerland.

Figure 6. Impact of the consolidation filter on the total volume of triadic patent families, according to the earliest priority date

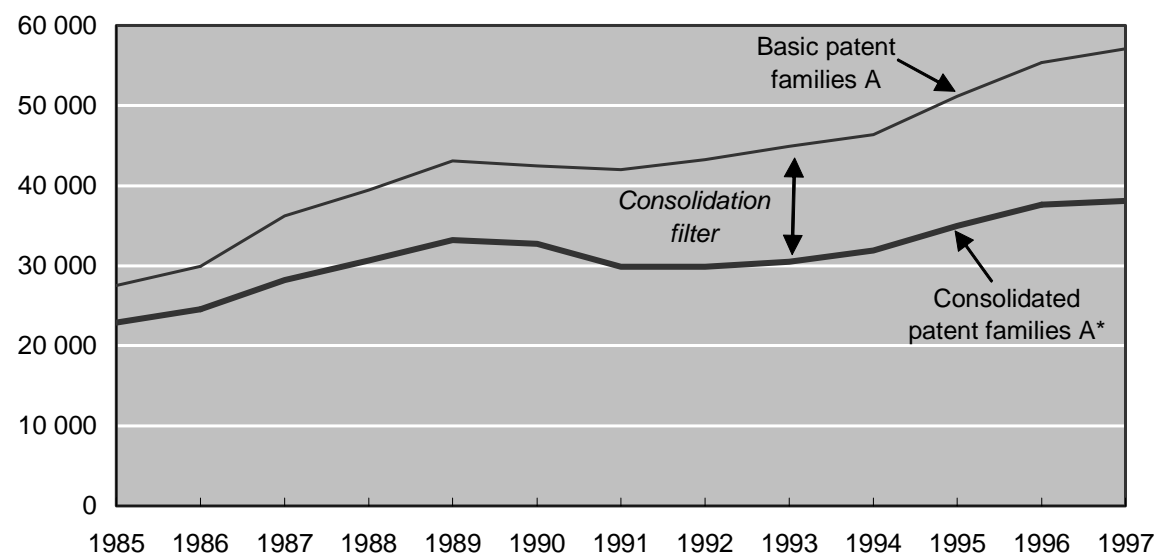

Source: OECD, Patent Database, October 2003.

34. For most countries, the rate of reduction in the numbers of patent families due to consolidation has been increasing during the period, with the exception of Japan, which has remained stable (39-40\%). This is mostly explained by the increasing proportion of EPO and USPTO patents with inter-related priorities: $35 \%$ of EPO patents included at least 2 different priorities in 1991 against $57 \%$ of EPO patents in 1997. Inventors or applicants are modifying their patent applications either to fulfil rules and regulations of patent offices or for strategic purposes. Annex table 7 shows the increasing proportion of triadic patent families based on more than 1 priority, after the consolidation filter is applied. The combinations of patents within one family are altered by the consolidation: $73 \%$ of triadic patent families are formed by a unique 
filing to EPO, USPTO and JPO in 1997 (against 80\% before consolidation). The proportion of families based on several JPO filings is increased by the consolidation filter: $5 \%$ triadic patent families have more than 2 JPO filings and only 1 filing to other offices, compared to 1 before consolidation, and $4 \%$ of families have more than 2 filings at all three offices (against $1.6 \%$ before).

35. Country shares in total patent families are significantly affected by the consolidation filter (see Figure 7 and Annex Tables 6 and 8): Japan looses nearly 2 percentage points in 1997 (from 28.2\% to $26.7 \%$ ), whereas the share for the United States was increased by almost 5 percentage points (from $30 \%$ to $35 \%$ ). Besides the positions of the United States and the European Union that have been inverted by the consolidation filter, most of the major patenting countries remain at their relative ranking. The empirical t-statistics and the correlation coefficients also show dissimilarities over time in the shares of the largest country.

Figure 7. Impact of the consolidation filter on country shares in total patent families, for priority date 1997
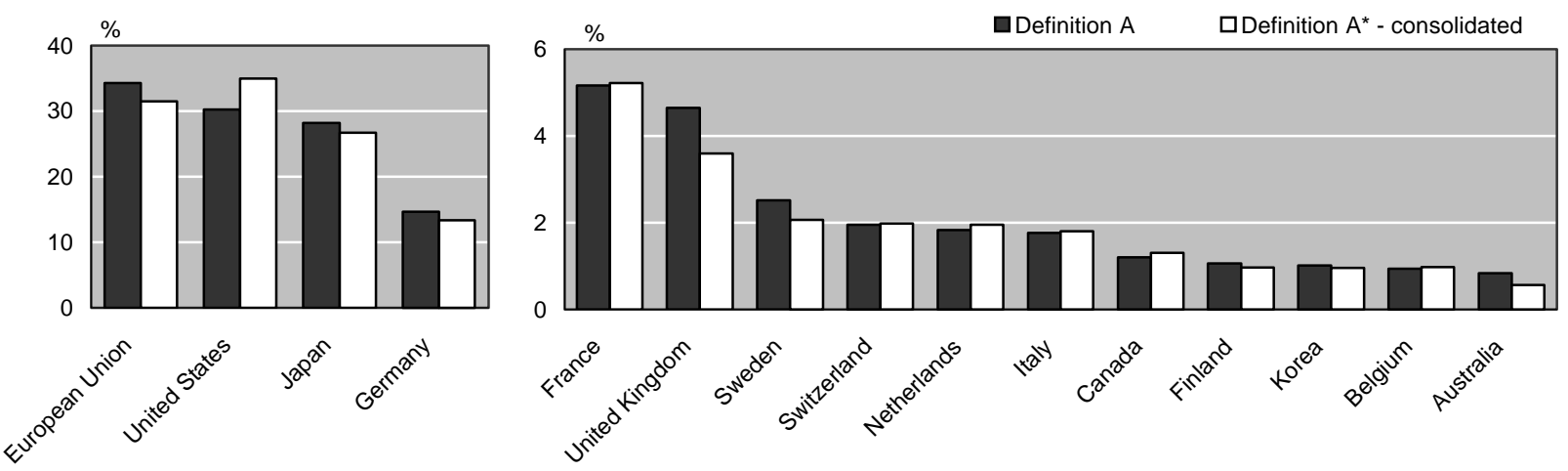

Source: OECD, Patent Database, October 2003.

36. The consolidation filter has a strong impact on the volume and on the structure of triadic patent families. It fulfils the background requirements behind the construction of patent families: providing to users a set of indicators with an enhanced international comparability. Combining inter-related priorities in the count of patent families removes most biases derived from the patent offices rules and regulations - or from country specific patenting strategies. The resulting indicators are changed, particularly in terms of country shares: in the case of Japan, its weight in the OECD total is reduced (mainly due to JPO patent structure of 1 priority leading to 1 patent application), whereas for the United States (where patent document tend to have more than 1 priority) the opposite holds.

\section{Definition of the triadic patent families}

37. The triadic patent families are defined at the OECD as a set of patents taken at the EPO, JPO and USPTO that share one or more priorities. In comparison with traditional indicators based on patent filings to a single patent office, the triadic patent families cover a homogeneous set of inventions as the most important inventions are deemed to be protected by a patent at the EPO, JPO and the USPTO. Furthermore, as shown in Figure 8 below, the resultant indicators are less influenced by patent offices' rules and regulations, and patenting strategies. Consequently, counting triadic patent families provides indicators of an improved quality and international comparability for measuring innovation performance of countries. 


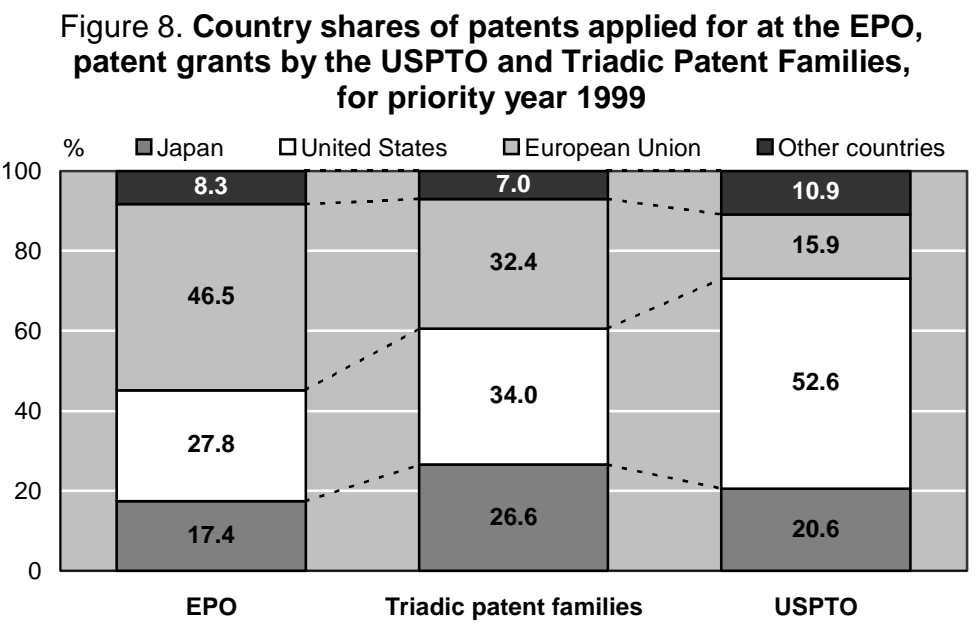

Source: OECD, Patent Database, October 2003.

\section{Criteria for counting patent families}

38. What an indicator reflects depends on the underlying methodology that is used to construct the indicator. Similarly to patent statistics derived from a single patent office, the counting procedure influences the interpretation of the resulting indicators. Patent indicators can reflect the inventive performance of a country, the ownerships of patent stock or the attractiveness of the country's patenting system, etc. according to the criteria chosen to measure the volume of patents. Therefore, the following choices have to be made on: a) the geographical distribution (priority country, inventor's country of residence, applicant's country of residence); b) the reference dates (priority, application, publication, and grant dates); and c) the count of patents involving multiple countries (Dernis et al. 2001).

39. Patent family counts by the inventor's country of residence indicate the inventiveness of the local labour force (researchers, laboratories) whereas counts based on the residence country of the applicant (owner of patent at the time of application) give a measure of control of the invention. Counts by priority country measure the attractiveness of the country's patenting process, and general economic features (e.g. market size, trade flows, etc.), etc. The most widely used geographical distribution is based on patent counts by the inventors' country of residence, although others are legitimate in their own way. Since the aim is to develop patent families indicators to measure inventive performance of countries, the preferable criteria is to count patent families according to the inventor's country of residence.

40. Patent documents provide various reference dates. The priority date, which is the earliest, is therefore closest to the invention date. To measure inventive performance at a given point in time, patent families indicators are calculated according to the priority date. For the triadic patent families, after the consolidation process, patent families could refer to one or more priorities, and, as consequence, to one or more priority dates. In the case of several priority dates for a same patent family, the earliest date is the preferred one, as it is closest to the original invention. The main drawback with selecting priority date for counting patent families is the increase in lag between priority date and the availability of information. The time lag between priority and publication dates is 18 months, while the time lag between priority and grant dates stands on average between 3 to 4 years. As a consequence, patent families are subject to the problem of timeliness. For example, from all the publicly available information in 2003, a data set of complete patent families can only be computed up to 1997.

41. Patents with multiple inventors from different countries can either be partly attributed to each country mentioned in the document (fractional counting) or fully attributed to every relevant country, thus generating multiple counting. In order to avoid double counting, and consequently to overestimate the 
volume of patent families, fractional counting is applied. For example, a patent family with two German, three French, and an English inventor will be counted as 1/3 for Germany, 1/2 for France and 1/6 for the United Kingdom.

42. In this paper, the patent families - calculated upon alternative definitions - are presented according to fractional counts on the inventor' countries and by the priority date (or the earliest priority date when the consolidation filter is applied).

\section{Patent application and grant data}

43. The OECD triadic patent families are based on the patent applications to the EPO, and the JPO, and patent granted by the USPTO. It would have been preferable to use patent application data for the three patent offices. Unfortunately the available information is asymmetric since the USPTO did not publish data on applications until 2001, so the only historical record of a patent at the USPTO available to the public until recently is that of patent grant documents. For this reason, USPTO patent grants data is used as a proxy for the USPTO applications. This asymmetric information on which the definition is based (applications and grants data) results in underestimated numbers of patent families. For the latest years, from 2001 onwards, it will be possible to rectify this situation by including data on patent applications to the USPTO that will improve the timeliness of the indicators based on the triadic patent families' definition. The impacts of replacing the USPTO patent grants data with the application data should be investigated in the future (once sufficient amount of data is available).

44. Patent applications do not automatically confer protection for the invention. Applications provide certain basic rights prior to grant (e.g. right to license, etc.). Only a proportion of the applications are successful, fulfilling the patenting criteria (e.g. the invention is novel, non-obvious and industrially applicable) and rules and regulations of the patent office. Instead of calculating patent families based on the application data, one could envisage calculating patent families based on the grant data. The consequence will be a considerable reduction in the volume of patent families, as patent families based on grant data are a subset of total patent families based on application data. The table below shows that around two-third of patents having a priority in the early 1990's have been subsequently granted by the EPO, this share represents around $78 \%$ for patent families. Therefore, restricting patent families to the EPO grants data would reduce the volume of families by at least a quarter (a larger reduction will occur with the inclusion of JPO grant). Furthermore, substituting application data with grant data will deteriorate the timeliness of the data as the grant process takes on average between three to four years at the USPTO and five years at the EPO (in some instances, the grants process last up to ten years).

\begin{tabular}{rrrrrrrrr}
\hline EPO grant rates (\%) by priority date & $\mathbf{1 9 9 0}$ & $\mathbf{1 9 9 1}$ & $\mathbf{1 9 9 2}$ & $\mathbf{1 9 9 3}$ & $\mathbf{1 9 9 4}$ & $\mathbf{1 9 9 5}$ & $\mathbf{1 9 9 6}$ & $\mathbf{1 9 9 7}$ \\
\hline In patent applications to the EPO & 66.7 & 66.8 & 67.7 & 66.4 & 62.0 & 55.9 & 45.2 & 32.5 \\
In Triadic patent families & 77.7 & 78.6 & 78.3 & 76.2 & 69.5 & 60.0 & 45.9 & 30.6 \\
\hline
\end{tabular}

Source: OECD, Patent Database, October 2003.

45. For measuring inventive performance, indicators based on applications are preferable to indicators based on grants data. Grants data are subset of total applications data. Measuring innovative performance using the grants data will provide a partial picture as it will discard the innovative effort of the unsuccessful patents, hence it is preferable to use patent indicators based on application data.

\section{Nowcasting patent families}

46. One of the drawbacks associated with the triadic patent families definition is the timeliness of indicators. This is due to two factors: the selection of priority date and the data on USPTO grants. The legal delay for publishing an application is 18 months after the priority date, as a consequence patent 


\section{DSTI/DOC(2004)2}

indicators based on priority dates are built with an automatic legal time lag of at least 18 months. Furthermore, the time lag between priority date and publication date is up to five years in the case of patent filed at the USPTO. Prior to change in the rule in November $2000^{13}$, the USPTO did not publish patent applications data 18 months after the priority date, as is the case for most patent offices. Publication of the USPTO patent applications only occurred once patents have been granted. As a consequence patent indicators based on USPTO data calculated according to the priority date will have an automatic legal time lag of 4 to 5 years. Patent statistics counted according to the year of grant may seem to provide a more up to date picture, but it is an artefact as the label (i.e. year) corresponds to the publication date and not to the date of invention. For example, in the case of a patent application filed at the USPTO in 1998 which is granted by the USPTO in 2003, grant date based statistics will record this patent for year 2003, whereas the date of invention is closer to year 1998. Measuring innovative activity using grant date based statistics will distort the measure of innovative activity because the statistics will also reflect the activity of the patent office (for further discussion on the priority and grant dates, see Dernis et al., 2001).

47. In order to improve the timeliness of triadic patent families, a nowcasting exercise (i.e. forecasting the recent past) is conducted at an aggregate level on a regular basis. Patent data reported here are based on the available information in July 2003. The data on filings to the EPO is available up to priority date 1999 because of the inclusion of the transferred international filings data (i.e. international patent application using the PCT (Patent Cooperation Treaty) procedure). The USPTO grant data is available up to priority date 1997, and the nowcasting method enables estimating data up to 1999. Further work is being conducted to develop models to improve the timeliness of the triadic patent families indicators.

\section{Measuring inventive performance of the OECD countries using triadic patent families}

\section{Counting triadic patent families}

The OECD triadic patent families are derived from patent applications to the EPO and the JPO, and patent granted by the USPTO. The criteria for counting the triadic patent families are the earliest priority date, the inventor's country of residence, using fractional counts. The nowcasting exercise has been conducted to provide statistics up to the priority year 1999.

48. The total number of triadic patent families grew continuously during the 1980 s, followed by a period of decline in the early 1990s (Figure 9). Since the mid-1990s, the growth rate of the number of triadic patent families resumed an upward trend. However, the latest available data show the rate of growth to be slowing down. A similar trend is observed for countries with a large triadic patent portfolio (such as the United States, Japan and Germany). In 1999, the total number of triadic patent families was estimated to be around 42600 , representing an average annual increase of more than 4\% from the 1991 level.

13. The final rules regarding the publication of patent applications have been published in the Federal Register (65 Fed. Reg. 57024, September 20th, 2000) and in the Official Gazette of the USPTO (1239 Off. Gez. Pat. Office 63, October 10th, 2000). 
Figure 9. Evolution of triadic patent families, by inventor's countries and priority date

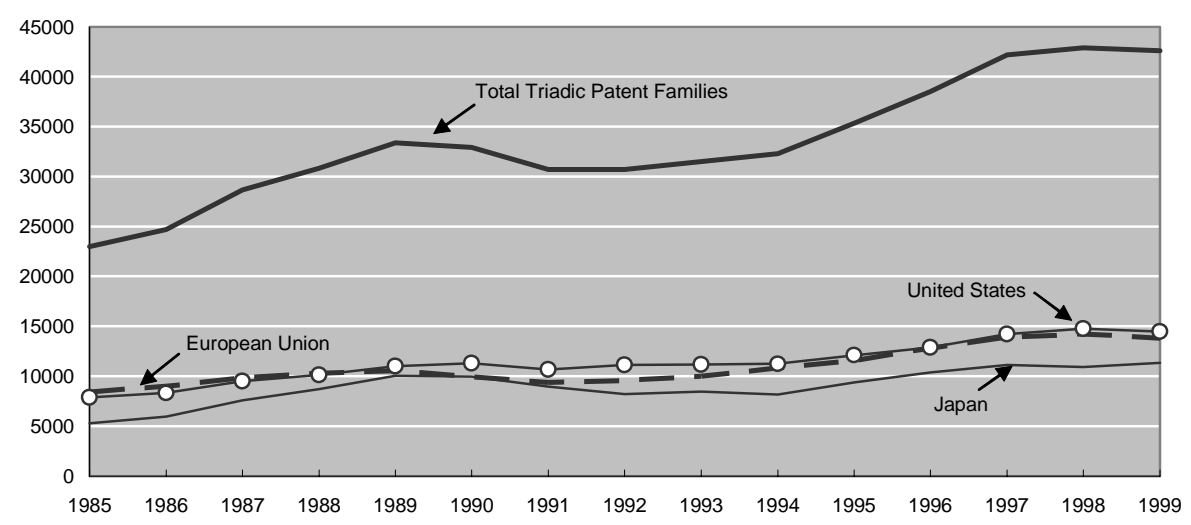

Source: OECD, Patent Database, October 2003.

49. The United States accounted for around 34.0\%, followed by the European Union (32.4\%) and Japan $(26.6 \%)$. Among the European countries, Germany has by the largest share with $14.1 \%$, more than the combine shares of France, the United Kingdom, Italy, and the Netherlands (see Figure 10). Notable changes in the share of triadic patent families between 1991 and 1999 are observed for the European Union and Germany (increases) and France, Japan and the United States (decreases). To standardize for the country size, triadic patent families are expressed relative to the population (see Figure 11 below). The European Union has a low propensity to patent (37 patent families for 1 million residents) in comparison to the United States (52) and Japan (89). Switzerland and Sweden are the two countries with more than 100 patent families per million population. Finland and Germany also have a high propensity to patent. For all reported countries, the number of triadic patent families per million population in 1999 has grown compared to 1991 level.

Figure 10. Share of countries in triadic patent families, by inventor's country for priority date 1997

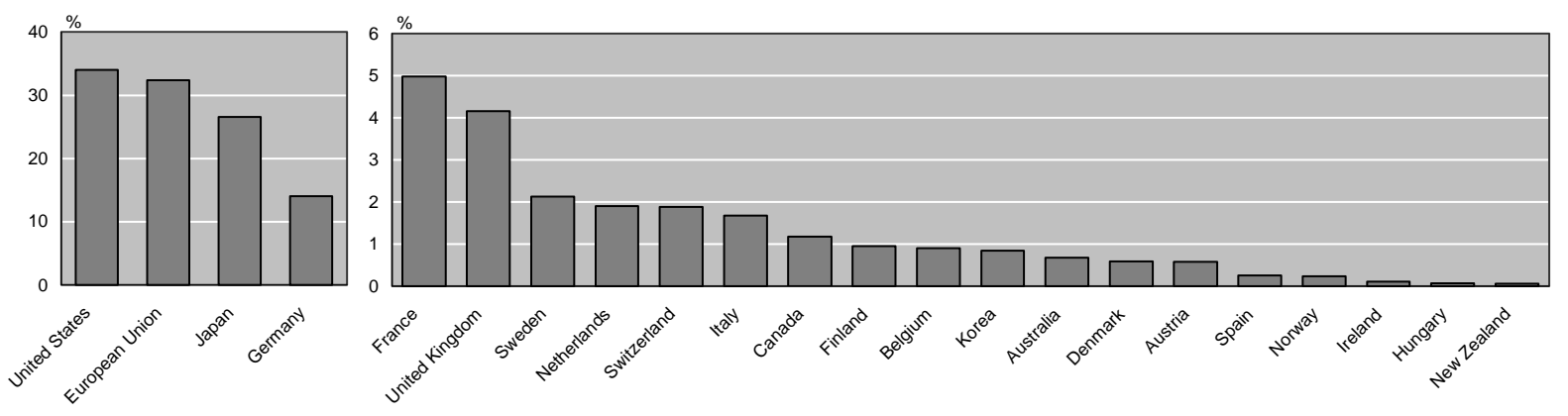

Figure 11. Number of triadic patent families per million population according to the residence of the inventors, for priority date 1999
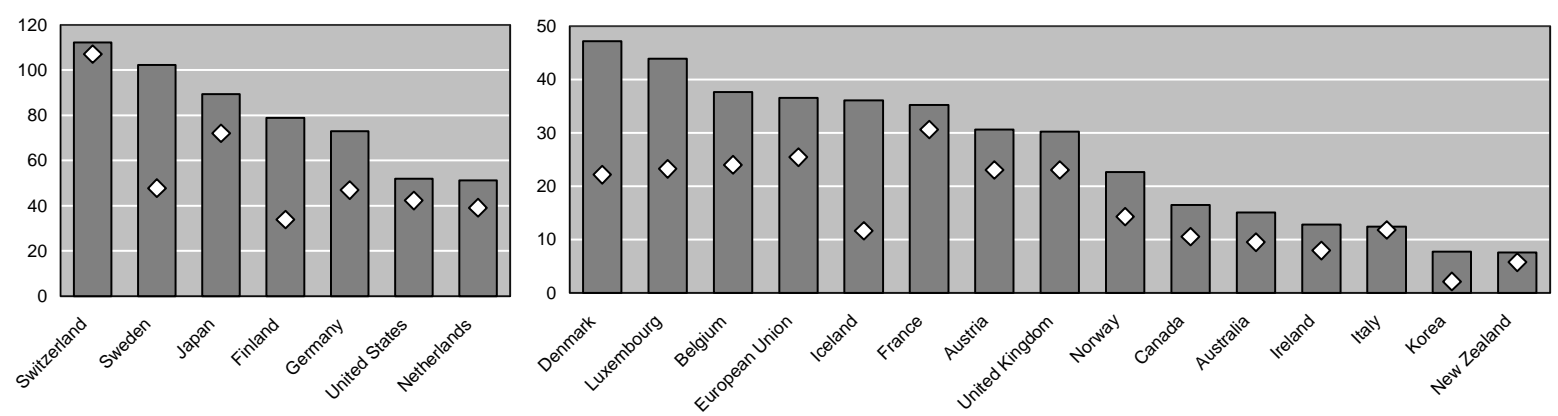

Source: OECD, Patent Database, October 2003. 


\section{DSTI/DOC(2004)2}

50. The European Union and Japan have a high patent intensity (triadic patent families divided by the industry-financed $R \& D$ expenditure) as compared with the United States (Figure 12). The patent intensity of the United States has remained stable for the last two decades. In the European Union and Japan, patent intensity followed a similar path of decrease during the late 1980s and early 1990s, with an increasing trend in the mid-1990s. The low patenting intensity of the United States is due to the significant increase in industry-financed R\&D expenditure during the 1990s. In the 1990s, expenditures in R\&D financed by the industry sector remained stable in the EU and Japan, while their number of triadic patent families increased. For this reason, both the EU and Japan have a higher patenting intensity compared to the United States.

Figure 12. Triadic patent families over industry-financed $R \& \mathbf{D}^{*}$ according to the residence of the inventors, by priority year; R\&D expenditures lagged by one year

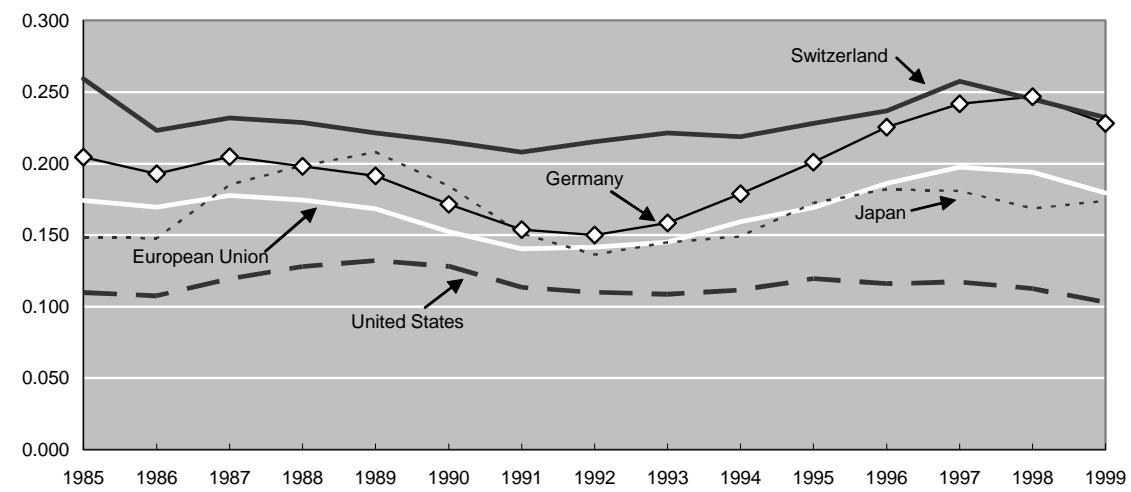

* Gross domestic expenditure on R\&D (GERD) financed by industry, million 1995 USD using purchasing power parities. Source: OECD, Patent Database, October 2003.

51. ICT and biotechnology patents are identified through the list of IPC classes and their respective specialisation index is depicted in Figure 13. The specialisation index is calculated as the ratio of the country share in patent families for a technological domain over its relative share in total patent families. Korea, Japan, the United States and two Nordic countries devote a large part of their patenting activity to ICT-related inventions. Canada, Denmark Norway, the United States and the United Kingdom tend to be specialised in biotechnology patents. 
Figure 13. Triadic patent families in selected technological areas according to the residence of the inventors, for priority date 1997
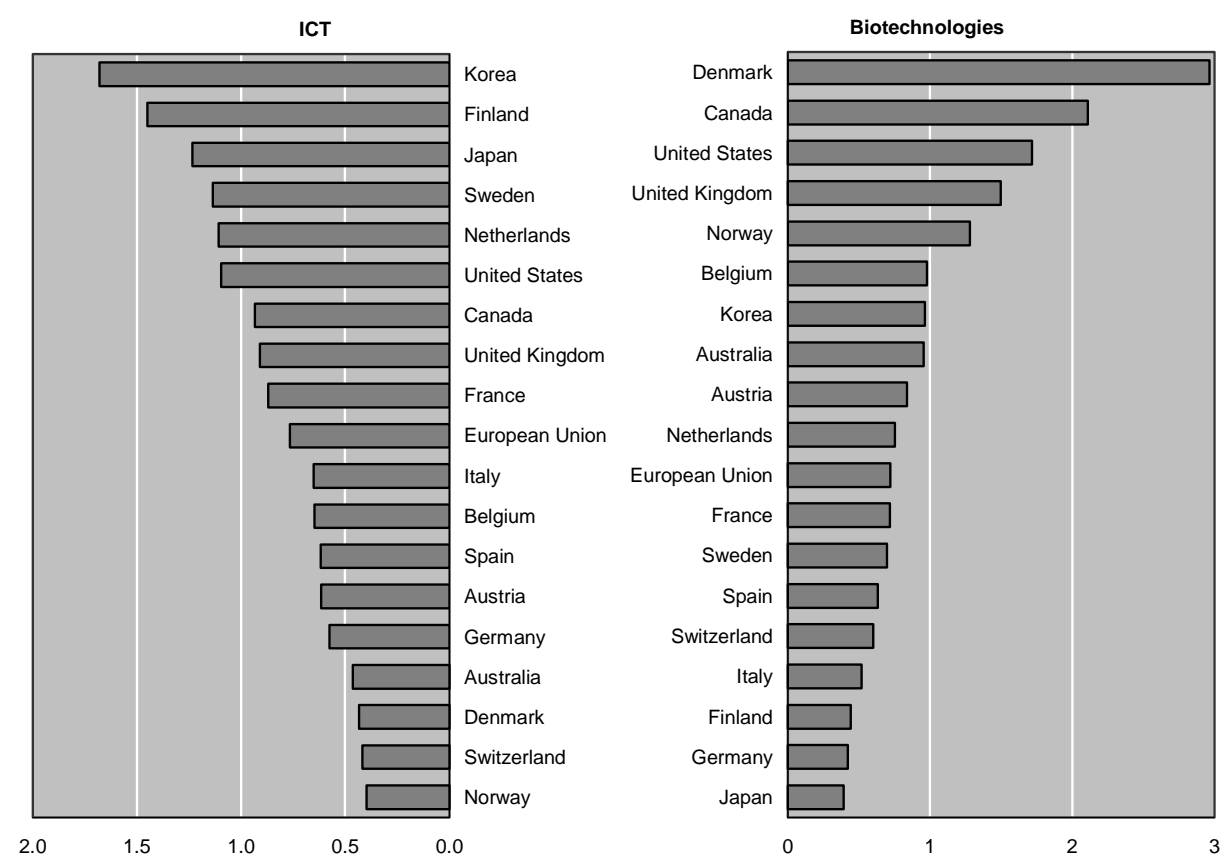

Cut off point: .Countries with more than 100 triadic patent families in 1997.

Source: OECD, Patent Database, October 2003.

\section{Conclusion}

52. Patent statistics are frequently used to address various science and technology policy issues. The most widely available and used patent statistics are based on filings to a specific patent office, such as the USPTO patent grants data, the EPO applications and grants data, international patent filings (PCT), etc. While their richness and strength are broadly recognised, those data show specific weakness as technology indicators. Furthermore the surge in patent filings across the world and changes in patenting dynamics have increased the source of noise associated with patent statistics and made it more complex to calculate and analyze them. In order to improve the quality and international comparability of the patent statistics, the OECD have developed a methodology (as discussed above) to calculate triadic patent families indicators. Indicators based on triadic patent families in addition to the traditional patent indicators will provide policy makers with a comprehensive set of indicators for measuring innovative activities of the OECD and non-OECD countries.

53. The OECD triadic patent families are defined as a set of patents taken at the EPO, JPO and USPTO that share one or more priorities. Patent families based on three different definitions were calculated and compared to each other. Comparisons of patent families' data have shown that lowering the threshold of the geographical filter to include patents filings to the French, and the German, and the UK patent offices (definition B) does not significantly increase the volume of patent families. However, if the geographical filter is lowered substantially (definition C), then the volume of patent families is significantly increased, but at the same time, the data suffer from biases and country specificities (especially for Japan and Korea), which has an adverse effect on international comparability. Hence, patent families based on definition $\mathrm{A}$ is preferable to the other two definitions, as patent families data based on definition A are free of home advantage, bilateral trade flow, market size, etc. biases.

54. The OECD triadic patent families are consolidated in order to eliminate double counting of similar inventions/patents. The consolidation process involves regrouping all the priorities that are 
inter-related in a EPO, JPO or USPTO patent document. It means that every direct and indirect linkage - that connects patent and priority filings together - are used to establish a patent family. The consolidation process suppresses patent overlaps that exist between patent documents of the office, and therefore removes the remaining specificity due to the rules and regulations of the offices involved in the definition. Patent examiners and searchers also use a similar approach when examining patent applications.

55. The triadic patent families' indicators improve the quality (by capturing the important inventions) and international comparability (by eliminating biases) of patent indicators. However there are two issues that need to be addressed in the future. The first issue deals with the inclusion of USPTO patent grants data instead of patent applications data, because of the unavailability of historical USPTO patent applications data. The second issue concerns the timeliness of the data due to the selection of priority date as the reference date and due to data on USPTO grants. A nowcasting exercise is conducted to improve the timeliness of the patent families data, however further effort is required to develop nowcasting models to improve the timeliness of the data.

56. Patent families data can be calculated based on alternative definitions; i.e. alternative geographical (different patent offices) filter, invention (non-consolidated, direct links, etc.) filter, reference date, etc. The selection of one definition over another is determined by the phenomena that are to be measured using the data. The definition presented and discussed here is best suited for measuring inventive performance. However, basic data are available to design patent families data set to meet different users' needs. 


\section{REFERENCES}

Dernis, H., D. Guellec and B. van Pottelsberghe (2001), "Using Patent Counts for Cross-country Comparisons of Technology Output", STI Review No. 27, OECD, Paris.

OECD (2003), "Compendium of Patent Statistics", OECD, Paris.

Grupp, H. and U. Schmoch (1999), "Patent Statistics in the Age of Globalisation: New Legal Procedures, New Analytical Methods, New Economic Interpretation”, Research Policy 28 (1999) 377-396.

Hingley, P. and W. G. Park (2003), "Patent Family Data and Statistics at the European Patent Office", paper presented at the WIPO-OECD Workshop on Statistics in the Patent Field, Geneva. 
ANNEX TABLES

Table 1. Country shares in patenting activity at the USPTO and at the EPO according to the residence of the inventors, by priority year.

\begin{tabular}{|c|c|c|c|c|c|c|c|c|}
\hline & \multicolumn{4}{|c|}{ Patent applications to the EPO } & \multicolumn{4}{|c|}{ Patents granted by the USPTO ${ }^{1}$} \\
\hline & 1980 & 1990 & 1995 & 1999 & 1980 & 1990 & 1995 & 1999 \\
\hline Australia & 0.99 & 0.59 & 0.70 & 0.87 & 0.47 & 0.51 & 0.48 & 0.49 \\
\hline Austria & 1.08 & 1.06 & 0.97 & 1.03 & 0.41 & 0.33 & 0.31 & 0.31 \\
\hline Belgium & 1.03 & 0.84 & 1.16 & 1.25 & 0.33 & 0.35 & 0.46 & 0.39 \\
\hline Canada & 0.83 & 0.90 & 1.17 & 1.48 & 1.67 & 1.89 & 1.94 & 2.05 \\
\hline Czech Republic & 0.00 & 0.04 & 0.03 & 0.06 & 0.07 & 0.02 & 0.02 & 0.02 \\
\hline Denmark & 0.62 & 0.54 & 0.70 & 0.79 & 0.22 & 0.24 & 0.26 & 0.31 \\
\hline Finland & 0.35 & 0.70 & 1.01 & 1.35 & 0.25 & 0.36 & 0.49 & 0.50 \\
\hline France & 9.78 & 8.04 & 7.40 & 6.92 & 3.29 & 3.04 & 2.62 & 2.34 \\
\hline Germany & 25.16 & 18.64 & 18.75 & 20.22 & 9.46 & 6.95 & 6.59 & 6.81 \\
\hline Greece & 0.03 & 0.04 & 0.04 & 0.05 & 0.01 & 0.02 & 0.01 & 0.01 \\
\hline Hungary & 0.34 & 0.11 & 0.08 & 0.10 & 0.19 & 0.05 & 0.04 & 0.04 \\
\hline Iceland & 0.01 & 0.01 & 0.01 & 0.03 & 0.00 & 0.01 & 0.01 & 0.01 \\
\hline Ireland & 0.10 & 0.11 & 0.14 & 0.21 & 0.04 & 0.06 & 0.06 & 0.09 \\
\hline Italy & 2.49 & 3.66 & 3.57 & 3.59 & 1.10 & 1.24 & 1.05 & 1.03 \\
\hline Japan & 11.08 & 21.22 & 17.73 & 17.35 & 15.77 & 23.71 & 20.59 & 20.55 \\
\hline Korea & 0.01 & 0.19 & 0.65 & 0.96 & 0.04 & 0.73 & 2.43 & 2.17 \\
\hline Luxembourg & 0.10 & 0.06 & 0.05 & 0.06 & 0.02 & 0.03 & 0.02 & 0.02 \\
\hline Mexico & 0.03 & 0.02 & 0.03 & 0.04 & 0.08 & 0.04 & 0.05 & 0.05 \\
\hline Netherlands & 2.74 & 2.49 & 2.50 & 2.82 & 1.04 & 0.88 & 0.86 & 0.76 \\
\hline New Zealand & 0.08 & 0.04 & 0.09 & 0.13 & 0.05 & 0.04 & 0.07 & 0.07 \\
\hline Norway & 0.21 & 0.21 & 0.34 & 0.35 & 0.11 & 0.12 & 0.15 & 0.14 \\
\hline Poland & 0.07 & 0.03 & 0.02 & 0.03 & 0.03 & 0.01 & 0.01 & 0.02 \\
\hline Portugal & 0.01 & 0.01 & 0.02 & 0.04 & 0.01 & 0.00 & 0.01 & 0.01 \\
\hline Slovak Republic & 0.00 & 0.00 & 0.01 & 0.02 & 0.00 & 0.00 & 0.00 & 0.01 \\
\hline Spain & 0.17 & 0.42 & 0.56 & 0.71 & 0.09 & 0.14 & 0.17 & 0.17 \\
\hline Sweden & 2.40 & 1.52 & 2.19 & 2.08 & 1.18 & 0.76 & 0.92 & 0.96 \\
\hline Switzerland & 4.24 & 2.76 & 2.43 & 2.39 & 1.68 & 1.15 & 0.91 & 0.80 \\
\hline Turkey & 0.00 & 0.01 & 0.01 & 0.02 & 0.00 & 0.00 & 0.01 & 0.01 \\
\hline United Kingdom & 8.47 & 5.82 & 5.46 & 5.43 & 3.44 & 2.62 & 2.41 & 2.23 \\
\hline United States & 26.31 & 28.47 & 30.51 & 27.85 & 57.77 & 52.69 & 54.09 & 52.60 \\
\hline European Union & 54.54 & 43.95 & 44.52 & 46.54 & 20.89 & 17.01 & 16.24 & 15.93 \\
\hline OECD & 98.75 & 98.55 & 98.34 & 98.24 & 98.83 & 97.97 & 97.04 & 94.95 \\
\hline Total Number of Patents & 24314 & 61249 & 69188 & 102246 & 67070 & 105755 & 141886 & 172980 \\
\hline
\end{tabular}

1. 1999 figures for USPTO grants are Secretariat estimates.

Source: OECD, Patent Database, October 2003. 
DSTI/DOC(2004)2

Table 2. Differences between definitions $A$ and $B$,

according to the residence of the inventors, by priority year.

\begin{tabular}{|c|c|c|c|c|c|c|c|c|c|c|c|}
\hline & \multicolumn{6}{|c|}{ Percentage differences: B - A } & \multicolumn{3}{|c|}{ Average (\%) } & \multicolumn{2}{|c|}{$\begin{array}{c}\text { Number of patent } \\
\text { families in } 1997\end{array}$} \\
\hline & 1985 & 1990 & 1994 & 1995 & 1996 & 1997 & $1985-97$ & $1985-90$ & $1991-97$ & A & B \\
\hline Australia & 5.75 & 2.28 & 0.21 & 0.73 & 0.44 & 0.48 & 1.52 & 2.49 & 0.51 & 482 & 484 \\
\hline Austria & 5.46 & 9.70 & 3.30 & 2.80 & 2.68 & 2.68 & 4.98 & 6.39 & 3.45 & 355 & 364 \\
\hline Belgium & 13.17 & 2.44 & 0.61 & 0.78 & 0.20 & 0.19 & 3.79 & 6.39 & 0.93 & 538 & 539 \\
\hline Canada & 8.30 & 2.08 & 1.70 & 1.68 & 0.77 & 0.26 & 2.18 & 3.23 & 0.85 & 690 & 691 \\
\hline Czech Republic & 15.00 & 5.52 & 0.00 & 0.00 & 0.00 & 0.00 & 8.00 & 13.88 & 0.97 & 12 & 12 \\
\hline Denmark & 17.46 & 3.70 & 0.00 & 0.26 & 0.00 & 0.27 & 3.82 & 6.85 & 0.60 & 376 & 377 \\
\hline Finland & 36.66 & 0.58 & 1.33 & 0.87 & 0.90 & 0.49 & 8.21 & 14.32 & 1.17 & 607 & 610 \\
\hline France & 5.72 & 1.13 & 0.49 & 0.72 & 0.47 & 0.57 & 2.00 & 3.10 & 0.75 & 2947 & 2964 \\
\hline Germany & 9.27 & 3.28 & 2.13 & 1.74 & 1.80 & 1.52 & 3.82 & 5.35 & 2.16 & 8381 & 8508 \\
\hline Greece & 66.67 & 0.00 & 0.00 & 0.00 & 0.00 & 0.00 & 5.13 & 9.52 & 0.00 & 17 & 17 \\
\hline Hungary & 42.78 & 12.37 & 1.15 & 0.00 & 0.00 & 0.00 & 18.33 & 32.61 & 2.76 & 50 & 50 \\
\hline Iceland & 0.00 & 0.00 & 0.00 & 0.00 & 0.00 & 0.00 & 0.00 & 0.00 & 0.00 & 6 & 6 \\
\hline Ireland & 9.80 & 2.39 & 0.00 & 0.00 & 0.00 & 0.00 & 1.80 & 2.94 & 0.60 & 50 & 50 \\
\hline Italy & 18.98 & 2.84 & 0.85 & 0.48 & 0.44 & 0.10 & 4.22 & 7.23 & 0.68 & 1008 & 1009 \\
\hline Japan & 10.13 & 2.79 & 0.90 & 0.99 & 1.28 & 0.74 & 3.30 & 5.18 & 1.31 & 16107 & 16226 \\
\hline Korea & 39.76 & 55.40 & 9.47 & 10.96 & 17.26 & 20.99 & 52.69 & 85.77 & 19.97 & 579 & 700 \\
\hline Luxembourg & 0.00 & 0.00 & 0.00 & 0.00 & 0.00 & 0.00 & 29.65 & 51.48 & 5.12 & 22 & 22 \\
\hline Mexico & 177.78 & 11.83 & 0.00 & 0.00 & 0.00 & 9.55 & 19.58 & 29.11 & 9.27 & 10 & 11 \\
\hline Netherlands & 3.36 & 0.30 & 0.24 & 0.00 & 0.00 & 0.00 & 0.53 & 0.92 & 0.09 & 1045 & 1045 \\
\hline New Zealand & 12.00 & 0.00 & 0.00 & 6.66 & 0.00 & 0.00 & 6.88 & 11.41 & 1.36 & 65 & 65 \\
\hline Norway & 16.84 & 1.63 & 0.00 & 0.00 & 0.00 & 0.00 & 2.37 & 4.29 & 0.31 & 169 & 169 \\
\hline Poland & 0.00 & 0.00 & 0.00 & 6.35 & 0.00 & 0.00 & 0.49 & 0.00 & 0.91 & 15 & 15 \\
\hline Portugal & 0.00 & 0.00 & 0.00 & 0.00 & 0.00 & 0.00 & 5.02 & 9.32 & 0.00 & 6 & 6 \\
\hline Slovak Republic & .. & .. & 0.00 & 0.00 & 0.00 & 0.00 & .. & .. & 0.00 & 4 & 4 \\
\hline Spain & 22.98 & 9.06 & 2.54 & 2.93 & 1.36 & 0.61 & 11.05 & 17.82 & 5.10 & 163 & 164 \\
\hline Sweden & 3.96 & 0.63 & 0.00 & 0.19 & 0.02 & 0.27 & 1.18 & 1.83 & 0.47 & 1437 & 1441 \\
\hline Switzerland & 7.63 & 1.94 & 1.94 & 1.35 & 1.02 & 0.40 & 3.16 & 4.67 & 1.59 & 1113 & 1118 \\
\hline Turkey & 0.00 & 133.33 & 0.00 & 69.86 & 0.00 & 0.00 & 16.68 & 21.00 & 9.98 & 4 & 4 \\
\hline United Kingdom & 6.78 & 1.88 & 0.61 & 0.69 & 0.43 & 0.28 & 2.11 & 3.45 & 0.56 & 2653 & 2660 \\
\hline United States & 8.88 & 2.26 & 1.13 & 0.90 & 0.84 & 0.79 & 2.80 & 4.34 & 1.05 & 17259 & 17396 \\
\hline European Union & 8.48 & 2.44 & 1.22 & 1.09 & 1.00 & 0.88 & 3.00 & 4.52 & 1.32 & 19604 & 19777 \\
\hline OECD & 9.18 & 2.63 & 1.16 & 1.11 & 1.18 & 1.00 & 3.14 & 4.78 & 1.35 & 56169 & 56729 \\
\hline Total Patents & 9.22 & 2.67 & 1.19 & 1.12 & 1.24 & 1.08 & 3.17 & 4.82 & 1.38 & 57089 & 57703 \\
\hline
\end{tabular}

Source: OECD, Patent Database, October 2003. 
Table 3. Differences between definitions $A$ and $C$, according to the residence of the inventors, by priority year.

\begin{tabular}{|c|c|c|c|c|c|c|c|c|c|c|c|}
\hline & \multicolumn{6}{|c|}{ Percentage differences: C - A } & \multicolumn{3}{|c|}{ Average (\%) } & \multicolumn{2}{|c|}{$\begin{array}{l}\text { Number of patent } \\
\text { families in } 1997\end{array}$} \\
\hline & 1985 & 1990 & 1994 & 1995 & 1996 & 1997 & $1985-97$ & $1985-90$ & $1991-97$ & A & C \\
\hline Australia & 20.91 & 9.99 & 4.33 & 4.83 & 3.99 & 5.26 & 7.47 & 9.95 & 4.66 & 482 & 507 \\
\hline Austria & 18.83 & 16.09 & 7.23 & 6.15 & 6.32 & 6.82 & 12.18 & 15.38 & 8.63 & 355 & 379 \\
\hline Belgium & 14.34 & 3.12 & 1.12 & 2.07 & 1.97 & 1.42 & 4.95 & 7.61 & 2.09 & 538 & 546 \\
\hline Canada & 15.83 & 6.28 & 4.90 & 4.32 & 6.19 & 2.88 & 7.29 & 9.10 & 5.18 & 690 & 709 \\
\hline Czech Republic & 90.00 & 13.81 & 1.38 & 3.07 & 0.00 & 8.01 & 24.24 & 35.58 & 10.72 & 12 & 13 \\
\hline Denmark & 31.64 & 10.43 & 1.75 & 1.15 & 0.70 & 1.40 & 9.85 & 16.97 & 2.01 & 376 & 381 \\
\hline Finland & 84.33 & 9.25 & 3.33 & 2.79 & 2.42 & 3.13 & 21.45 & 36.50 & 4.49 & 607 & 626 \\
\hline France & 11.88 & 3.94 & 2.79 & 3.66 & 3.19 & 3.82 & 5.43 & 6.82 & 3.74 & 2947 & 3060 \\
\hline Germany & 27.13 & 12.70 & 12.26 & 10.30 & 9.17 & 8.98 & 15.05 & 18.24 & 12.08 & 8381 & 9134 \\
\hline Greece & 66.67 & 0.00 & 0.00 & 0.00 & 0.00 & 0.00 & 6.54 & 12.15 & 0.72 & 17 & 17 \\
\hline Hungary & 60.61 & 20.61 & 1.15 & 0.00 & 0.00 & 0.33 & 25.81 & 45.51 & 4.21 & 50 & 50 \\
\hline Iceland & 200.00 & 0.00 & 0.00 & 0.00 & 0.00 & 0.00 & 23.08 & 42.86 & 0.00 & 6 & 6 \\
\hline Ireland & 14.69 & 6.75 & 1.06 & 0.87 & 0.30 & 3.02 & 3.30 & 4.40 & 1.92 & 50 & 51 \\
\hline Italy & 22.95 & 6.95 & 2.34 & 2.73 & 1.94 & 1.08 & 7.55 & 12.00 & 2.74 & 1008 & 1019 \\
\hline Japan & 65.43 & 28.81 & 27.20 & 26.98 & 27.02 & 25.61 & 33.65 & 39.81 & 26.38 & 16107 & 20231 \\
\hline Korea & 112.05 & 210.24 & 112.19 & 127.18 & 166.84 & 114.69 & 211.93 & 281.26 & 155.24 & 579 & 1243 \\
\hline Luxembourg & 0.00 & 4.87 & 14.66 & 0.00 & 0.00 & 0.00 & 39.44 & 64.87 & 13.21 & 22 & 22 \\
\hline Mexico & 411.11 & 11.83 & 0.00 & 11.28 & 0.00 & 28.64 & 43.37 & 67.06 & 15.51 & 10 & 13 \\
\hline Netherlands & 4.18 & 1.82 & 0.94 & 0.25 & 0.55 & 0.28 & 1.42 & 2.02 & 0.99 & 1045 & 1048 \\
\hline New Zealand & 24.00 & 22.33 & 14.73 & 21.10 & 5.43 & 3.07 & 24.01 & 36.25 & 9.76 & 65 & 67 \\
\hline Norway & 30.88 & 4.07 & 4.09 & 4.63 & 6.00 & 3.85 & 7.33 & 10.26 & 3.91 & 169 & 175 \\
\hline Poland & 74.07 & 0.00 & 0.00 & 6.35 & 0.00 & 0.00 & 8.07 & 13.07 & 1.91 & 15 & 15 \\
\hline Portugal & 0.00 & 0.00 & 0.00 & 0.00 & 0.00 & 0.00 & 8.31 & 15.44 & 0.00 & 6 & 6 \\
\hline Slovak Republic & .. & .. & 0.00 & 0.00 & 0.00 & 50.63 & .. & .. & 10.13 & 4 & 6 \\
\hline Spain & 40.81 & 15.24 & 3.39 & 5.74 & 2.04 & 2.96 & 15.74 & 24.17 & 8.10 & 163 & 168 \\
\hline Sweden & 11.66 & 4.50 & 1.63 & 0.73 & 1.56 & 2.37 & 5.28 & 7.71 & 2.61 & 1437 & 1471 \\
\hline Switzerland & 12.59 & 4.85 & 4.47 & 3.94 & 3.26 & 2.54 & 6.05 & 7.86 & 4.25 & 1113 & 1142 \\
\hline Turkey & 0.00 & 133.33 & 0.00 & 69.86 & 13.19 & 0.00 & 21.89 & 28.79 & 11.86 & 4 & 4 \\
\hline United Kingdom & 11.00 & 5.40 & 3.39 & 3.96 & 4.02 & 4.72 & 5.80 & 7.06 & 4.60 & 2653 & 2778 \\
\hline United States & 17.99 & 7.30 & 6.59 & 6.03 & 6.63 & 6.49 & 8.63 & 10.52 & 6.55 & 17259 & 18378 \\
\hline European Union & 19.31 & 8.32 & 6.46 & 5.84 & 5.43 & 5.62 & 9.67 & 12.33 & 6.98 & 19604 & 20705 \\
\hline OECD & 33.76 & 16.15 & 13.06 & 13.13 & 13.56 & 12.63 & 17.80 & 21.65 & 13.61 & 56169 & 63265 \\
\hline Total Patents & 33.89 & 16.17 & 13.02 & 13.09 & 13.57 & 12.69 & 17.82 & 21.69 & 13.61 & 57089 & 64332 \\
\hline
\end{tabular}

Source: OECD, Patent Database, October 2003. 
Table 4. Country shares in total patent families: averages, correlation coefficients and t-ratios for definitions $A, B$ and $C$, according to the residence of the inventors, by priority year.

\begin{tabular}{|c|c|c|c|c|c|c|c|c|c|c|}
\hline & \multicolumn{2}{|c|}{ A } & \multicolumn{4}{|c|}{ B } & \multicolumn{4}{|c|}{ C } \\
\hline & $1985-90$ & $1991-97$ & $1985-90$ & $1991-97$ & $\begin{array}{c}\text { Correl. with A } \\
(1985-97)\end{array}$ & $\begin{array}{l}\text { t-ratios }{ }^{1} \\
\text { B vs. A }\end{array}$ & $1985-90$ & $1991-97$ & $\begin{array}{c}\text { Correl. with A } \\
(1985-97)\end{array}$ & $\begin{array}{l}\text { t-ratios }{ }^{1} \\
\text { C vs. A }\end{array}$ \\
\hline Australia & 0.56 & 0.87 & 0.55 & 0.86 & 1.000 & 0.131 & 0.51 & 0.80 & 0.997 & 0.829 \\
\hline Austria & 0.56 & 0.60 & 0.57 & 0.62 & 0.962 & -0.449 & 0.53 & 0.58 & 0.930 & 1.320 \\
\hline Belgium & 0.59 & 0.93 & 0.60 & 0.93 & 0.998 & -0.032 & 0.52 & 0.84 & 0.999 & 1.078 \\
\hline Canada & 0.81 & 1.00 & 0.80 & 1.00 & 0.999 & 0.143 & 0.72 & 0.93 & 0.992 & 1.463 \\
\hline Czech Republic & 0.03 & 0.03 & 0.03 & 0.03 & 0.854 & -0.447 & 0.03 & 0.03 & 0.730 & -0.436 \\
\hline Denmark & 0.35 & 0.65 & 0.36 & 0.64 & 0.999 & -0.005 & 0.34 & 0.58 & 0.998 & 0.605 \\
\hline Finland & 0.32 & 0.93 & 0.35 & 0.93 & 0.999 & -0.084 & 0.36 & 0.86 & 0.998 & 0.181 \\
\hline France & 5.14 & 5.12 & 5.06 & 5.08 & 0.984 & 0.620 & 4.50 & 4.67 & 0.742 & $6.313^{a}$ \\
\hline Germany & 12.45 & 13.25 & 12.51 & 13.35 & 0.999 & -0.155 & 12.02 & 13.05 & 0.985 & 0.617 \\
\hline Greece & 0.01 & 0.02 & 0.01 & 0.02 & 0.993 & 0.022 & 0.01 & 0.02 & 0.994 & 0.540 \\
\hline Hungary & 0.11 & 0.08 & 0.14 & 0.08 & 0.929 & -0.914 & 0.13 & 0.07 & 0.922 & -0.444 \\
\hline Iceland & 0.00 & 0.01 & 0.00 & 0.01 & 1.000 & 0.053 & 0.00 & 0.01 & 0.980 & 0.170 \\
\hline Ireland & 0.07 & 0.09 & 0.07 & 0.09 & 0.995 & 0.154 & 0.06 & 0.08 & 0.984 & 1.574 \\
\hline Italy & 1.78 & 1.73 & 1.83 & 1.72 & 0.948 & -0.390 & 1.64 & 1.57 & 0.975 & $4.163^{a}$ \\
\hline Japan & 35.56 & 30.27 & 35.67 & 30.26 & 0.999 & -0.028 & 40.98 & 33.65 & 0.946 & $-2.626^{b}$ \\
\hline Korea & 0.08 & 0.71 & 0.14 & 0.82 & 0.994 & -0.520 & 0.24 & 1.51 & 0.979 & $-2.038^{c}$ \\
\hline Luxembourg & 0.03 & 0.03 & 0.04 & 0.03 & 0.855 & -0.637 & 0.04 & 0.03 & 0.863 & -0.144 \\
\hline Mexico & 0.01 & 0.02 & 0.01 & 0.02 & 0.939 & -0.367 & 0.01 & 0.02 & 0.911 & -0.083 \\
\hline Netherlands & 1.92 & 1.81 & 1.84 & 1.79 & 0.985 & 0.737 & 1.59 & 1.61 & 0.863 & $4.462^{a}$ \\
\hline New Zealand & 0.04 & 0.09 & 0.04 & 0.09 & 0.997 & -0.092 & 0.04 & 0.09 & 0.978 & -0.005 \\
\hline Norway & 0.16 & 0.30 & 0.16 & 0.29 & 0.999 & 0.075 & 0.14 & 0.27 & 0.997 & 0.686 \\
\hline Poland & 0.01 & 0.03 & 0.01 & 0.03 & 1.000 & 0.078 & 0.01 & 0.03 & 0.994 & 0.403 \\
\hline Portugal & 0.00 & 0.01 & 0.00 & 0.01 & 0.984 & -0.011 & 0.00 & 0.01 & 0.977 & 0.407 \\
\hline Slovak Republic & 0.00 & 0.01 & 0.00 & 0.01 & 0.993 & -0.061 & 0.00 & 0.01 & 0.980 & 0.021 \\
\hline Spain & 0.15 & 0.25 & 0.17 & 0.26 & 0.987 & -0.540 & 0.15 & 0.24 & 0.987 & 0.296 \\
\hline Sweden & 1.27 & 2.15 & 1.23 & 2.13 & 0.999 & 0.129 & 1.12 & 1.94 & 0.996 & 0.840 \\
\hline Switzerland & 2.43 & 2.06 & 2.43 & 2.07 & 0.998 & 0.008 & 2.14 & 1.89 & 0.992 & $2.363^{b}$ \\
\hline Turkey & 0.00 & 0.00 & 0.00 & 0.00 & 0.936 & -0.236 & 0.00 & 0.00 & 0.900 & 0.051 \\
\hline United Kingdom & 4.90 & 5.30 & 4.83 & 5.26 & 0.998 & 0.292 & 4.28 & 4.88 & 0.932 & $2.897^{a}$ \\
\hline United States & 29.77 & 30.38 & 29.65 & 30.28 & 0.997 & 0.350 & 26.97 & 28.49 & 0.839 & $5.976^{a}$ \\
\hline European Union & 29.55 & 32.88 & 29.47 & 32.86 & 0.999 & 0.042 & 27.16 & 30.94 & 0.979 & $1.898^{c}$ \\
\hline OECD & 99.13 & 98.74 & 99.10 & 98.70 & 0.998 & 0.289 & 99.10 & 98.74 & 0.990 & 0.139 \\
\hline Total Patents & 100 & 100 & 100 & 100 & & & 100 & 100 & & \\
\hline
\end{tabular}

1. The t-distribution gives critical values of $2.797,2.064$ and 1.711 for the 1 percent, 5 percent and 10 percent levels. Superscripts $\mathrm{a}, \mathrm{b}$ and $\mathrm{c}$ denote significance at respectively 1,5 and 10 percent levels.

Source: OECD, Patent Database, October 2003. 
Table 5. Ranking of countries based on average shares in total families 1997, according to definitions $A, B$ and $C$

\begin{tabular}{|c|c|c|c|c|c|c|}
\hline & \multicolumn{2}{|c|}{ A } & \multicolumn{2}{|c|}{ B } & \multicolumn{2}{|c|}{ C } \\
\hline & Share & Rank & Share & Rank & Share & Rank \\
\hline European Union & 34.34 & 1 & 34.27 & 1 & 32.19 & 1 \\
\hline United States & 30.23 & 2 & 30.15 & 2 & 28.57 & $\underline{3}$ \\
\hline Japan & 28.21 & 3 & 28.12 & 3 & 31.45 & $\underline{2}$ \\
\hline Germany & 14.68 & 4 & 14.74 & 4 & 14.20 & 4 \\
\hline France & 5.16 & 5 & 5.14 & 5 & 4.76 & 5 \\
\hline United Kingdom & 4.65 & 6 & 4.61 & 6 & 4.32 & 6 \\
\hline Sweden & 2.52 & 7 & 2.50 & 7 & 2.29 & 7 \\
\hline Switzerland & 1.95 & 8 & 1.94 & 8 & 1.77 & $\underline{9}$ \\
\hline Netherlands & 1.83 & 9 & 1.81 & 9 & 1.63 & $\underline{10}$ \\
\hline Italy & 1.77 & 10 & 1.75 & 10 & 1.58 & $\underline{11}$ \\
\hline Canada & 1.21 & 11 & 1.20 & $\underline{12}$ & 1.10 & $\underline{12}$ \\
\hline Finland & 1.06 & 12 & 1.06 & $\underline{13}$ & 0.97 & $\underline{13}$ \\
\hline Korea & 1.01 & 13 & 1.21 & $\underline{11}$ & 1.93 & $\underline{8}$ \\
\hline Belgium & 0.94 & 14 & 0.93 & 14 & 0.85 & 14 \\
\hline Australia & 0.84 & 15 & 0.84 & 15 & 0.79 & 15 \\
\hline Denmark & 0.66 & 16 & 0.65 & 16 & 0.59 & 16 \\
\hline Austria & 0.62 & 17 & 0.63 & 17 & 0.59 & 17 \\
\hline Norway & 0.30 & 18 & 0.29 & 18 & 0.27 & 18 \\
\hline Spain & 0.29 & 19 & 0.28 & 19 & 0.26 & 19 \\
\hline New Zealand & 0.11 & 20 & 0.11 & 20 & 0.10 & 20 \\
\hline Hungary & 0.09 & 21 & 0.09 & 21 & 0.08 & $\underline{22}$ \\
\hline Ireland & 0.09 & 22 & 0.09 & 22 & 0.08 & $\underline{21}$ \\
\hline Luxembourg & 0.04 & 23 & 0.04 & 23 & 0.03 & 23 \\
\hline Greece & 0.03 & 24 & 0.03 & 24 & 0.03 & 24 \\
\hline Poland & 0.03 & 25 & 0.03 & 25 & 0.02 & 25 \\
\hline Czech Republic & 0.02 & 26 & 0.02 & 26 & 0.02 & 26 \\
\hline Mexico & 0.02 & 27 & 0.02 & 27 & 0.02 & 27 \\
\hline Portugal & 0.01 & 28 & 0.01 & 28 & 0.01 & $\underline{29}$ \\
\hline Iceland & 0.01 & 29 & 0.01 & 29 & 0.01 & $\underline{30}$ \\
\hline Turkey & 0.01 & 30 & 0.01 & 30 & 0.01 & $\underline{31}$ \\
\hline Slovak Republic & 0.01 & 31 & 0.01 & 31 & 0.01 & $\underline{28}$ \\
\hline Total Patents & 100 & & 100 & & 100 & \\
\hline
\end{tabular}

Source: OECD, Patent Database, October 2003. 
DSTI/DOC(2004)2

Table 6. Differences due to the consolidation filter applied to definition A according to the residence of the inventors, by priority year.

\begin{tabular}{|c|c|c|c|c|c|c|c|c|c|}
\hline & \multicolumn{5}{|c|}{ Triadic patent families $A^{*}$} & \multicolumn{4}{|c|}{ Country shares in total patent families $A^{*}$} \\
\hline & \multicolumn{3}{|c|}{ Average reduction (\%) } & \multicolumn{2}{|c|}{ Number of families - 1997} & \multirow{2}{*}{$1985-90$} & \multirow{2}{*}{$1991-97$} & \multirow{2}{*}{$\begin{array}{c}\text { Correlation } \\
\text { with A } \\
1985-97 \\
\end{array}$} & \multirow{2}{*}{$\begin{array}{l}\text { t-ratios }{ }^{1} \\
A^{*} \text { vs } A\end{array}$} \\
\hline & $1985-97$ & $1985-90$ & $1991-97$ & A & $A^{*}$ & & & & \\
\hline Australia & -38.26 & -21.38 & -52.72 & 482 & 214 & 0.56 & 0.60 & 0.650 & $2.324^{b}$ \\
\hline Austria & -23.29 & -11.44 & -33.44 & 355 & 239 & 0.63 & 0.58 & 0.610 & -0.869 \\
\hline Belgium & -18.38 & -7.65 & -27.59 & 538 & 373 & 0.69 & 0.98 & 0.988 & -0.961 \\
\hline Canada & -19.93 & -10.54 & -27.98 & 690 & 497 & 0.91 & 1.05 & 0.945 & -1.411 \\
\hline Czech Republic & -30.26 & -14.74 & -43.56 & 12 & 9 & 0.03 & 0.02 & 0.369 & 0.772 \\
\hline Denmark & -33.22 & -16.72 & -47.37 & 376 & 186 & 0.37 & 0.49 & 0.984 & 1.329 \\
\hline Finland & -24.33 & -8.17 & -38.18 & 607 & 369 & 0.37 & 0.83 & 0.990 & 0.234 \\
\hline France & -16.33 & -6.01 & -25.18 & 2947 & 1987 & 6.11 & 5.57 & 0.438 & $-5.397^{a}$ \\
\hline Germany & -20.20 & -7.88 & -30.76 & 8381 & 5086 & 14.50 & 13.28 & 0.477 & $-1.954^{c}$ \\
\hline Greece & -25.56 & -9.96 & -38.92 & 17 & 8 & 0.01 & 0.02 & 0.858 & 0.147 \\
\hline Hungary & -25.96 & -9.39 & -40.16 & 50 & 28 & 0.13 & 0.07 & 0.961 & -0.112 \\
\hline Iceland & -28.69 & -23.46 & -33.17 & 6 & 4 & 0.00 & 0.01 & 0.939 & -0.006 \\
\hline Ireland & -30.06 & -17.86 & -40.51 & 50 & 31 & 0.07 & 0.08 & 0.691 & 1.106 \\
\hline Italy & -15.91 & -6.45 & -24.01 & 1008 & 686 & 2.10 & 1.92 & 0.749 & $-4.494^{\mathrm{a}}$ \\
\hline Japan & -38.96 & -39.91 & -38.14 & 16107 & 10193 & 27.11 & 27.23 & 0.554 & $4.464^{\mathrm{a}}$ \\
\hline Korea & -30.77 & -26.25 & -34.64 & 579 & 367 & 0.07 & 0.67 & 0.997 & 0.168 \\
\hline Luxembourg & -18.49 & -7.83 & -27.62 & 22 & 14 & 0.04 & 0.03 & 0.927 & -0.473 \\
\hline Mexico & -14.42 & -3.41 & -23.86 & 10 & 10 & 0.01 & 0.02 & 0.846 & -0.659 \\
\hline Netherlands & -16.07 & -6.38 & -24.37 & 1045 & 746 & 2.28 & 1.99 & 0.899 & $-3.111^{a}$ \\
\hline New Zealand & -31.19 & -12.42 & -47.27 & 65 & 33 & 0.04 & 0.07 & 0.845 & 0.875 \\
\hline Norway & -31.97 & -13.11 & -48.13 & 169 & 81 & 0.18 & 0.22 & 0.892 & 1.344 \\
\hline Poland & -24.28 & -7.06 & -39.04 & 15 & 8 & 0.01 & 0.02 & 0.722 & 0.496 \\
\hline Portugal & -10.95 & 8.89 & -27.97 & 6 & 6 & 0.01 & 0.01 & 0.869 & -0.397 \\
\hline Slovak Republic & .. & .. & -58.98 & 4 & 3 & 0.00 & 0.00 & 0.843 & 0.990 \\
\hline Spain & -21.94 & -8.25 & -33.66 & 163 & 96 & 0.18 & 0.24 & 0.926 & -0.249 \\
\hline Sweden & -26.07 & -8.24 & -41.34 & 1437 & 786 & 1.48 & 1.82 & 0.923 & 0.443 \\
\hline Switzerland & -18.51 & -9.40 & -26.32 & 1113 & 757 & 2.79 & 2.21 & 0.939 & $-1.804^{c}$ \\
\hline Turkey & -5.97 & 31.53 & -38.12 & 4 & 3 & 0.00 & 0.00 & 0.922 & -0.550 \\
\hline United Kingdom & -32.22 & -16.82 & -45.42 & 2653 & 1372 & 5.15 & 4.21 & 0.123 & $2.157^{b}$ \\
\hline United States & -17.26 & -11.57 & -22.13 & 17259 & 13325 & 33.26 & 34.49 & 0.817 & $-11.108^{a}$ \\
\hline European Union & -21.86 & -9.07 & -32.81 & 19604 & 11985 & 33.96 & 32.07 & 0.290 & -1.578 \\
\hline OECD & -26.56 & -20.93 & -31.40 & 56169 & 37517 & 99.07 & 98.77 & 0.977 & 0.127 \\
\hline Total Patents & -26.55 & -20.88 & -31.42 & 57089 & 38086 & 100.00 & 100.00 & & \\
\hline
\end{tabular}

1. The t-distribution gives critical values of $2.797,2.064$ and 1.711 for the 1 percent, 5 percent and 10 percent levels. Superscripts $a, b$ and $c$ denote significance at respectively 1,5 and 10 percent levels.

Source: OECD, Patent Database, October 2003. 
Table 7. Change in the structure of triadic patent families

combination of patents before and after consolidation, by priority year.

\begin{tabular}{|c|c|c|c|c|c|c|c|c|c|c|}
\hline \multirow[b]{2}{*}{ Proportion of patent families including } & \multicolumn{5}{|c|}{ Triadic patent families - A } & \multicolumn{5}{|c|}{ Triadic patent families - consolidated - $\mathbf{A}^{*}$} \\
\hline & 1985 & 1990 & 1995 & 1996 & 1997 & 1985 & 1990 & 1995 & 1996 & 1997 \\
\hline 1 filing at EPO,JPO,USPTO & 82.7 & 77.6 & 76.4 & 77.9 & 79.8 & 77.0 & 72.4 & 70.6 & 71.8 & 73.1 \\
\hline 1 filing at USPTO, JPO and more than 2 EPO filings & 1.8 & 2.5 & 2.9 & 2.7 & 2.4 & 0.9 & 1.5 & 2.4 & 2.4 & 2.4 \\
\hline 1 filing at EPO, USPTO and more than 2 JPO filings & 1.3 & 1.4 & 1.9 & 1.9 & 1.2 & 7.1 & 6.6 & 5.3 & 5.3 & 4.7 \\
\hline 1 filing at EPO, JPO and more than 2 USPTO filings & 10.6 & 14.1 & 13.6 & 12.5 & 12.1 & 8.4 & 10.5 & 11.8 & 11.4 & 11.1 \\
\hline 1 filing at JPO and more than 2 EPO and USPTO filings & 1.5 & 2.5 & 2.3 & 1.8 & 1.6 & 1.0 & 1.8 & 2.7 & 2.2 & 2.1 \\
\hline 1 filing at EPO and more than 2 USPTO and JPO filings & 1.0 & 0.8 & 0.8 & 0.6 & 0.4 & 2.2 & 2.0 & 1.7 & 1.4 & 1.2 \\
\hline 1 filing at USPTO and more than 2 EPO and JPO filings & 0.3 & 0.3 & 0.6 & 0.8 & 0.9 & 0.8 & 1.1 & 1.1 & 1.2 & 1.3 \\
\hline More than 2 filings at EPO,JPO,USPTO & 0.8 & 0.9 & 1.6 & 1.7 & 1.6 & 2.7 & 4.0 & 4.4 & 4.3 & 4.0 \\
\hline 1 priority filing & 100 & 100 & 100 & 100 & 100 & 68.22 & 44.45 & 32.55 & 32.10 & 31.60 \\
\hline More than 2 priority filings & .. & .. & .. & .. & .. & 31.8 & 55.5 & 67.5 & 67.9 & 68.4 \\
\hline
\end{tabular}

Source: OECD, Patent Database, October 2003.

Table 8. Impact of consolidation on countries' ranking based on average shares in total families

1997, according to definitions $A$ and $A^{*}$

\begin{tabular}{|c|c|c|c|c|}
\hline & \multicolumn{2}{|c|}{ A } & \multicolumn{2}{|c|}{$A^{*}$} \\
\hline & Share & Rank & Share & Rank \\
\hline European Union & 34.34 & 1 & 31.47 & $\underline{2}$ \\
\hline United States & 30.23 & 2 & 34.99 & 1 \\
\hline Japan & 28.21 & 3 & 26.76 & 3 \\
\hline Germany & 14.68 & 4 & 13.35 & 4 \\
\hline France & 5.16 & 5 & 5.22 & 5 \\
\hline United Kingdom & 4.65 & 6 & 3.60 & 6 \\
\hline Sweden & 2.52 & 7 & 2.06 & 7 \\
\hline Switzerland & 1.95 & 8 & 1.99 & 8 \\
\hline Netherlands & 1.83 & 9 & 1.96 & 9 \\
\hline Italy & 1.77 & 10 & 1.80 & 10 \\
\hline Canada & 1.21 & 11 & 1.30 & 11 \\
\hline Finland & 1.06 & 12 & 0.97 & $\underline{13}$ \\
\hline Korea & 1.01 & 13 & 0.96 & $\underline{14}$ \\
\hline Belgium & 0.94 & 14 & 0.98 & $\underline{12}$ \\
\hline Australia & 0.84 & 15 & 0.56 & $\underline{16}$ \\
\hline Denmark & 0.66 & 16 & 0.49 & 17 \\
\hline Austria & 0.62 & 17 & 0.63 & $\underline{15}$ \\
\hline Norway & 0.30 & 18 & 0.21 & $\underline{19}$ \\
\hline Spain & 0.29 & 19 & 0.25 & $\underline{18}$ \\
\hline New Zealand & 0.11 & 20 & 0.09 & 20 \\
\hline Hungary & 0.09 & 21 & 0.07 & $\underline{22}$ \\
\hline Ireland & 0.09 & 22 & 0.08 & $\underline{21}$ \\
\hline Luxembourg & 0.04 & 23 & 0.04 & 23 \\
\hline Greece & 0.03 & 24 & 0.02 & $\underline{27}$ \\
\hline Poland & 0.03 & 25 & 0.02 & $\underline{26}$ \\
\hline Czech Republic & 0.02 & 26 & 0.02 & $\underline{25}$ \\
\hline Mexico & 0.02 & 27 & 0.03 & $\underline{24}$ \\
\hline Portugal & 0.01 & 28 & 0.01 & 28 \\
\hline Iceland & 0.01 & 29 & 0.01 & 29 \\
\hline Turkey & 0.01 & 30 & 0.01 & 30 \\
\hline Slovak Republic & 0.01 & 31 & 0.01 & 31 \\
\hline Total Patents & 100 & & 100 & \\
\hline
\end{tabular}

Source: OECD, Patent Database, October 2003. 